Article

\title{
Bioclimatic Analysis in Pre-Design Stage of Passive House in Indonesia
}

\author{
Santy ${ }^{1, *}$, Hiroshi Matsumoto ${ }^{2}$, Kazuyo Tsuzuki ${ }^{2}$ and Lusi Susanti ${ }^{3}$ \\ 1 Industrial Engineering Department, University of Pembangunan Nasional Veteran Jakarta, JL RS Fatmawati, \\ Pondok Labu, Jakarta Selatan 12450, Indonesia \\ 2 Architecture and Civil Engineering Department, Toyohashi University of Technology, Toyohashi, \\ 1-1 Hibarigaoka, Tenpaku Cho, Toyohashi-shi 441-8580 Japan; matsu@ace.tut.ac.jp (H.M.); \\ tsuzuki@ace.tut.ac.jp (K.T.) \\ 3 Industrial Engineering Department, Andalas University, Fakultas Teknik, Kampus Limau Manis, \\ Padang 25163, Indonesia; lusi@ft.unand.ac.id \\ * Correspondence: santy@upnvj.ac.id; Tel.: +81-90-3258-9130
}

Academic Editor: Adrian Pitts

Received: 14 October 2016; Accepted: 6 March 2017; Published: 10 March 2017

\begin{abstract}
The objective of this study is to investigate the climate characteristics of Indonesian regions using an Olgyay Bioclimatic chart, a Givoni-Milne Bioclimatic chart and a Mahoney Table as the pre-design stage in the development of a passive house design standard for residential house construction in Indonesia. Jakarta was the city chosen for deep analysis, because it represents most of the Indonesian regions in terms of temperature and relative humidity. The Olgyay Bioclimatic chart showed that the climate needs a high wind velocity to counteract the vapor pressure and shading in order to reduce solar gain entering the building. The Givoni-Milne Bioclimatic chart proposed natural ventilation and shading devices, while the Mahoney Table recommends open spaces for protection against hot wind, rooms single-banked and permanent provision for air movement. The composite size of the opening at body height is better to allow the wind to counter the high levels of humidity and temperature. Heavy walls and roofs are suggested, as well as the provision of protection devices for the high amount of rainfall. Energy simulation was also done to investigate the effectiveness of the passive strategy proposed by the bioclimatic analysis. These results give a contribution as the indispensable basis for the development of a passive house standard in Indonesia.
\end{abstract}

Keywords: thermal comfort; passive design; Olgyay Bioclimatic chart; Givoni-Milne Bioclimatic chart; Mahoney Table; energy simulation

\section{Introduction}

Indonesia is a tropical country located between $6^{\circ} 08^{\prime} \mathrm{N}-11^{\circ} 15^{\prime} \mathrm{S}$ and $94^{\circ} 45^{\prime}-141^{\circ} 05^{\prime} \mathrm{E}$. It has only two seasons each year, a dry and a wet season. Data gathered from Green Building Studio (Autodesk) [1] showed that the average and maximum outdoor temperature are $26^{\circ} \mathrm{C}$ and $37^{\circ} \mathrm{C}$, respectively, while the average relative humidity ranged between $73 \%$ and $100 \%$ (Figure 1) [2]. The wind speed varies between 0.3 and $8.6 \mathrm{~m} / \mathrm{s}$. Most of the Indonesian regions experience rainfall between 1000 and $4000 \mathrm{~mm} /$ year. The climate is generally hot and humid with only a small variation of temperature throughout the year. 


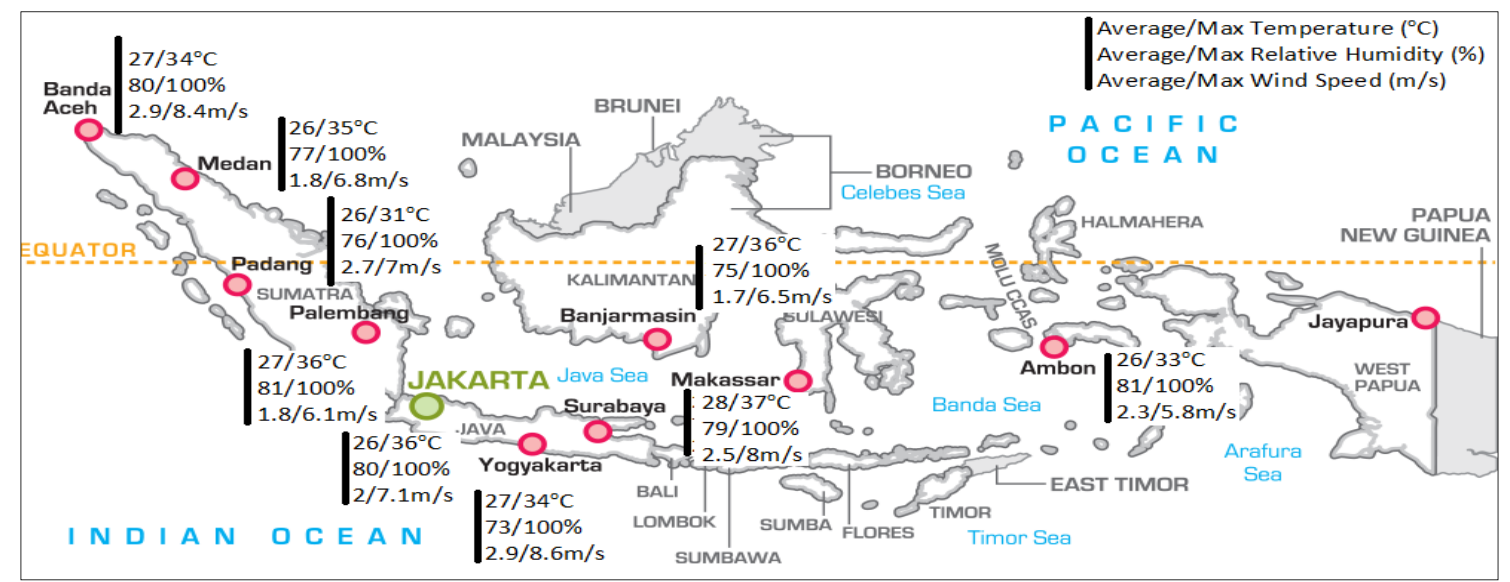

Figure 1. Map of Indonesia with temperature, relative humidity and wind speed (blank Indonesian map from [3]).

As climate is an important element when considering human comfort, an evaluation of the existing climatic conditions of a region will provide the possibility to understand how these climatic elements can be altered to achieve a greater level of human comfort. There are several tools noted in the literature to analyze climate conditions, including the Olgyay Bioclimatic chart, the Szokolay Bioclimatic chart, the Givoni-Milne Bioclimatic chart and the Mahoney Table. The Olgyay Bioclimatic chart is the first bioclimatic chart that connects temperature and relative humidity in order to define a comfort zone. There were few solutions provided by this chart when the climate was out of the comfort zone. There are only shading devices available for when the temperature is above $20^{\circ} \mathrm{C}$, and wind speed is required when the climate is too hot and humid. The Givoni-Milne Bioclimatic chart is mainly applied for residential-scale construction [4], and it provides more alternatives with building design to enable thermal comfort, including natural ventilation, evaporative cooling, thermal mass, passive heating, conventional air conditioning or dehumidification. The Givoni-Milne Bioclimatic chart [5] has also been used by previous researchers to investigate possible passive techniques for different types of climates around the world [4,6-12]. Lam et al. [6] investigated 18 cities in China, which represented five different climates (severe cold, cold, hot summer and cold winter, mild and hot summer and warm winter) and proposed an appropriate passive design strategy for each climate by analyzing the climate using this chart. Sayigh and Marafia [4] also utilized this chart to seek the proper passive strategy for building in the hot desert climate of Qatar. The analysis indicated a need for a high mass building coupled with night ventilation to restore comfort levels. In addition, dehumidification and passive heating might be applied during December-February.

The next tool for climatic analysis is the Szokolay Bioclimatic chart. Szokolay developed a new Bioclimatic chart based on the correction of a comfort zone by taking into consideration thermal neutrality, as provided by Humphreys and Auliciems [4]. Therefore, the new comfort zone in this chart is valid only for regions with a relative humidity of no more than $90 \%$. The Mahoney Table was introduced by the Department of Development of Tropical Studies of the Architectural Association in London, and it provides an analysis of the climate based on temperature, relative humidity and amount of precipitation/rainfall. The output of this table will determine the design recommendation for the layout, spacing, ventilation for air movement, building envelope (walls and roof), building opening, outdoor space and rain protection. All of these tools are widely used by researchers to investigate appropriate design recommendations for different climates around the world. A comparison between these tools is provided in Table 1. As climatic analysis for building design in Indonesia utilizing the tools described above is limited, this paper aims to investigate a design strategy for residential houses in Indonesia that will be appropriate for the climate. 
Table 1. Summary of climatic analysis tools for building design purposes.

\begin{tabular}{|c|c|c|c|c|}
\hline & Olgyay Bioclimatic Chart & Szokolay Bioclimatic Chart & Givoni-Milne Bioclimatic Chart & Mahoney Table \\
\hline $\begin{array}{l}\text { Monitored ambient } \\
\text { variables }\end{array}$ & $\begin{array}{ll}\text { 1. } & \text { Dry bulb temperature } \\
\text { 2. } & \text { Relative humidity }\end{array}$ & $\begin{array}{ll}\text { 1. } & \text { Dry bulb temperature } \\
\text { 2. } & \text { Wet bulb temperature } \\
\text { 3. } & \text { Relative humidity } \\
\text { 4. } & \text { Absolute humidity }\end{array}$ & $\begin{array}{ll}\text { 1. } & \text { Dry bulb temperature } \\
\text { 2. } & \text { Wet bulb temperature } \\
\text { 3. } & \text { Relative humidity } \\
\text { 4. } & \text { Absolute humidity } \\
\text { 5. } & \text { Vapor pressure }\end{array}$ & $\begin{array}{l}\text { 1. Monthly mean min, max and } \\
\text { average temperature } \\
\text { 2. Monthly mean min, max and } \\
\text { average relative humidity } \\
\text { 3. Precipitation }\end{array}$ \\
\hline $\begin{array}{c}\text { Strategy proposed/ } \\
\text { Design recommendation }\end{array}$ & $\begin{array}{ll}\text { 1. } & \text { Solar radiation } \\
\text { 2. } & \text { Air movement } \\
\text { 3. } & \text { Shading }\end{array}$ & $\begin{array}{ll}\text { 1. } & \text { Natural ventilation } \\
\text { 2. } & \text { Passive heating } \\
\text { 3. } & \text { Evaporative cooling } \\
\text { 4. } & \text { Indirect evaporative cooling } \\
\text { 5. } & \text { Thermal mass } \\
\text { 6. } & \text { Thermal mass with } \\
& \text { nigh ventilation }\end{array}$ & $\begin{array}{ll}\text { 1. } & \text { Natural ventilation } \\
\text { 2. } & \text { Passive heating } \\
\text { 3. } & \text { Active heating } \\
\text { 4. } & \text { Humidification } \\
\text { 5. } & \text { Conventional dehumidification } \\
\text { 6. } & \text { High thermal mass } \\
\text { 7. } & \text { High thermal mass with } \\
& \text { night ventilation } \\
\text { 8. Evaporative cooling } \\
\text { 9. } \\
\begin{array}{l}\text { air conventional/mechanical } \\
\text { aning }\end{array}\end{array}$ & $\begin{array}{ll}\text { 1. } & \text { Layout } \\
\text { 2. } & \text { Spacing } \\
\text { 3. } & \text { Air movement } \\
\text { 4. } & \text { Openings } \\
\text { 5. } & \text { Walls } \\
\text { 6. } & \text { Roofs } \\
\text { 7. } & \text { Outdoor space } \\
\text { 8. } & \text { Rain protection }\end{array}$ \\
\hline Limitation & $\begin{array}{l}\text { Only provides limited } \\
\text { design recommendation }\end{array}$ & $\begin{array}{l}\text { 1. The relative humidity should } \\
\text { not exceed } 90 \%\end{array}$ & $\begin{array}{l}\text { 1. Windows are closed during the } \\
\text { daytime for thermal mass }\end{array}$ & $\begin{array}{l}\text { 2. The thermal comfort limit assumes } \\
\text { no heat gain or loss due to } \\
\text { ventilation or insulation }\end{array}$ \\
\hline
\end{tabular}




\section{Literature Review}

\subsection{Passive Houses in Warm Climates}

A passive house is a concept for energy-efficient buildings that can provide a high level of comfort for occupants. The exact definition is as follows [13]:

"A Passive House is a building, in which thermal comfort (ISO 7730) can be provided solely by post heating or post cooling the fresh air flow which is required for good indoor air quality (DIN 1946)—without using recirculated air in addition"

Based on the definition of a passive house, it is clearly stated that the thermal comfort standard used for the requirement of passive house certification is ISO 7730, which is based on the study by Fanger [14]. The reasons for this are clearly described by Schneiders [15]. However, a further investigation is needed to investigate the possibility for the applicability of adaptive thermal comfort to the requirement of passive houses. Moreover, it is a challenge to compare the gap (if any) to the energy needs to achieve the comfort level by both adaptive and conventional comfort standards.

The certification criteria of a residential passive house are fully described in the guideline [16], including heating/cooling energy demand, primary energy demand and the airtightness. The energy for cooling/heating is $15 \mathrm{kWh} / \mathrm{m}^{2} \mathrm{a}$. The energy needs defined here are the energy needs to gain or lose the heat, and not the electrical energy that needs to be purchased. There is a special variable limit for cooling and dehumidification fraction demand, which is subject to the climate data, required air change rate and internal moisture load. The frequency of overheating in these criteria is indoor temperature above $25{ }^{\circ} \mathrm{C}$, with a border of $10 \%$ or less for houses without active cooling. The maximum humidity level allowed $12 \mathrm{~g} / \mathrm{kg}$ with a frequency of excessively high humidity of $20 \%$ or less.

There are five principles for the development of passive houses: airtightness, thermal bridges free-design, thermal insulation, passive house windows and ventilation. Although the basic original concept of passive design is mainly for reducing the heating demand in winter, as it was developed firstly in Germany (Central Europe), it is now to be applied to warm, hot and dry or humid and also tropical climates. In the projects Passive House in Different Climate and Passive House in Tropical Climate $[17,18]$, by Passipedia and partners, a reference passive house was built, and dynamic simulations using several design parameters were conducted. The design parameters studied were compactness, insulation for the walls, roof and basement ceiling, infiltration, heat recovery for ventilation, infiltration, glass and frame type, window area, orientation, solar absorption coefficient of external surface and heat capacity. Based on this study, appropriate design principles for a passive house are listed in Table 2, and the summary is described below.

In a warm climate, high temperature is the main problem that should be solved. However, in a hot and humid or tropical climate, not only high temperature, but also a high level of humidity should be taken into consideration. In these climates, an installation of heat and humidity recovery is sometimes needed, which has proven to recover about $70 \%-80 \%$ of the heat and humidity level. The building compactness affects the cooling need, but is not so significant. The insulation of the wall is suggested for this climate and contrary to the cooler climate, internal installation is more advisable in tropical climates. As the ground temperature in most regions in warm-climate countries is higher than the desired indoor temperature (for example, in Indonesia, the ground temperature is $28^{\circ} \mathrm{C}$ ), insulation for the floor slab or basement ceiling is needed to block the heat rising from the surface of the floor. The airtightness of the building envelope in warm climates is just as important as in a cool climate, because it can reduce the heat loss and the infiltration of humid air, which can cause discomfort and generate mold on the building envelope surface. The internal mass does not give an effect in a tropical climate, but slightly reduces the heating load in winter in a hot and dry climate (for example, Las Vegas). Double or triple low-e glazing with a low g-value is recommended for the window. Low absorptivity paint will also help to reduce energy consumption for cooling, as it can minimize the heat loss by the conduction through the building envelope. 
Table 2. Passive house strategy in warm climates.

\begin{tabular}{|c|c|c|c|}
\hline Climate & $\begin{array}{l}\text { Investigated Region, } \\
\text { Country or City }\end{array}$ & Climate Characteristic & Passive Strategy \\
\hline \multirow[b]{2}{*}{ Warm } & $\begin{array}{l}\text { Southwest Europe (12 selected } \\
\text { locations in Portugal, Spain, } \\
\text { Italy and Southern France) }\end{array}$ & Temperature: $-5-32{ }^{\circ} \mathrm{C}$ & $\begin{array}{l}\text { - } \\
\text { - } \quad \text { (making use of cold night air), } \\
\text { - } \quad \text { A supply air cooling (and dehumidification) system } \\
\text { - } \quad \text { Roof: } u \text {-value: } 0.16 \mathrm{~W} / \mathrm{m}^{2} \mathrm{~K} \\
\text { - } \quad \text { Uninsulated basement } \\
\text { - } \quad \text { Exterior blind combined with heat recovery } \\
\text { - } \quad \text { Thermal mass is useful, but less important }\end{array}$ \\
\hline & $\begin{array}{c}\text { New Zealand (Auckland, } \\
\text { Wellington and Christchurch) }\end{array}$ & Temperature: $6-24^{\circ} \mathrm{C}$ & $\begin{array}{l}\text { - Heat recovery } \\
\text { - } \text { Airtight building envelope with night ventilation in summer. } \\
\text { - Wall: } u \text {-value: } 0.155-0.449 \mathrm{~W} / \mathrm{m}^{2} \mathrm{~K} \text {, insulation thickness: } 6-20 \mathrm{~cm} \\
\text { - } \quad \text { Roof: } u \text {-value: } 0.128-0.415 \mathrm{~W} / \mathrm{m}^{2} \mathrm{~K} \text {, insulation thickness: } 6-25 \mathrm{~cm} \\
\text { - } \text { Basement ceiling: } u \text {-value: } \\
\text { - } 0.417-0.798 \mathrm{~W} / \mathrm{m}^{2} \mathrm{~K} \\
\text { - Window frame: } u \text { value: } 1.6 \mathrm{~W} / \mathrm{m}^{2} \mathrm{~K} \\
\text { - } \quad \text { Low-e double glazing: } u \text {-value: } 1.19 \mathrm{~W} / \mathrm{m}^{2} \mathrm{~K} \\
\text { - Window frame: } u \text {-value: } 0.72 \mathrm{~W} / \mathrm{m}^{2} \mathrm{~K} \\
\text { - }\end{array}$ \\
\hline Hot dry climates & Las Vegas & $\begin{array}{c}\text { Winter temperature: } 0-20^{\circ} \mathrm{C} \\
\text { Summer temperature: } 15-45^{\circ} \mathrm{C} \\
\text { Humidity: } 2-15 \mathrm{~g} / \mathrm{kgDA}\end{array}$ & $\begin{array}{l}\text { - Wall: } u \text {-value: } 0.125 \mathrm{~W} / \mathrm{m}^{2} \mathrm{~K} \text {, insulation thickness: } 25 \mathrm{~cm} \\
\text { - } \quad \text { Roof: } u \text {-value: } 0.2 \mathrm{~W} / \mathrm{m}^{2} \mathrm{~K} \text {, insulation thickness: } 15 \mathrm{~cm} \\
\text { - } \quad \text { Basement ceiling: } u \text {-value } 1.661 \mathrm{~W} / \mathrm{m}^{2} \mathrm{~K} \\
\text { - } \quad \text { Air change rate at } 50 \mathrm{~Pa}: 0.5 / \mathrm{h} \\
\text { - } \quad \text { Window frame: } u \text { value: } 1.6 \mathrm{~W} / \mathrm{m}^{2} \mathrm{~K} \\
\text { - } \quad \text { Glazing: } u \text {-value: } 1.19 \mathrm{~W} / \mathrm{m}^{2} \mathrm{~K}, g \text {-value: } 0.31 \\
\text { - } \quad \text { Movable shading } \\
\text { - } \quad \text { Cooling via supply air }\end{array}$ \\
\hline
\end{tabular}


Table 2. Cont

\begin{tabular}{|c|c|c|c|}
\hline Climate & $\begin{array}{l}\text { Investigated Region, } \\
\text { Country or City }\end{array}$ & Climate Characteristic & Passive Strategy \\
\hline Hot humid & Dubai & $\begin{array}{l}\text { Temperature: } 25-45^{\circ} \mathrm{C} \\
\text { Humidity: } 5-25 \mathrm{~g} / \mathrm{kgDA}\end{array}$ & $\begin{array}{l}\text { - } \quad \text { Wall: } u \text {-value } 0.125 \mathrm{~W} / \mathrm{m}^{2} \mathrm{~K} \text {, insulation thickness: } 25 \mathrm{~cm} \\
\text { - } \quad \text { Roof } u \text {-value } 0.155 \mathrm{~W} / \mathrm{m}^{2} \mathrm{~K} \text {, insulation thickness: } 20 \mathrm{~cm} \\
\text { - } \quad \text { Air change rate at } 50 \mathrm{~Pa}: 0.5 / \mathrm{h} \\
\text { - } \quad \text { Heat and humidity recovery for ventilation system. } \\
\text { - } \quad \text { Triple glazing with long eaves } \\
\text { - } \quad \text { Internal mass is not needed } \\
\text { - } \quad \text { Absorption coefficient of the external wall/roof: } 0.15 \\
\text { - } \quad \text { Overnight ventilation via windows } \\
\text { - } \quad \text { Climatization via supply air } \\
\text { - } \quad \text { Humidity control for cooling }\end{array}$ \\
\hline \multirow[b]{2}{*}{ Tropical climates } & $\begin{array}{c}\text { Salvador da Bahia } \\
\text { Mumbai } \\
\text { Singapore }\end{array}$ & \multirow{2}{*}{$\begin{array}{l}\text { Temperature: } 25-30{ }^{\circ} \mathrm{C} \\
\text { Humidity: } 15-20 \mathrm{~g} / \mathrm{kgDA}\end{array}$} & $\begin{array}{l}\text { - Wall: } u \text {-value: } 0.202 \mathrm{~W} / \mathrm{m}^{2} \mathrm{~K} \text {, insulation thickness: } 15 \mathrm{~cm} \\
\text { - } \quad \text { Roof: } u \text {-value: } 0.279 \mathrm{~W} / \mathrm{m}^{2} \mathrm{~K} \text {, insulation thickness: } 10 \mathrm{~cm} \\
\text { - } \quad \text { Basement ceiling: } u \text {-value } 0.357 \mathrm{~W} / \mathrm{m}^{2} \mathrm{~K} \\
\text { - } \quad \text { Air change rate at } 50 \mathrm{~Pa}: 0.5 / \mathrm{h} \\
\text { - } \quad \text { Window frame: } u \text {-value: } 1.6 \mathrm{~W} / \mathrm{m}^{2} \mathrm{~K} \\
\text { - } \quad \text { Glazing: } u \text {-value: } 1.1 \mathrm{~W} / \mathrm{m}^{2} \mathrm{~K}, g \text {-value: } 0.23 \\
\text { - } \quad \text { Shading: roof overhang: } 1.5 \mathrm{~m} \\
\text { - } \quad \text { Mechanical ventilation with energy recovery }\end{array}$ \\
\hline & Mexico & & 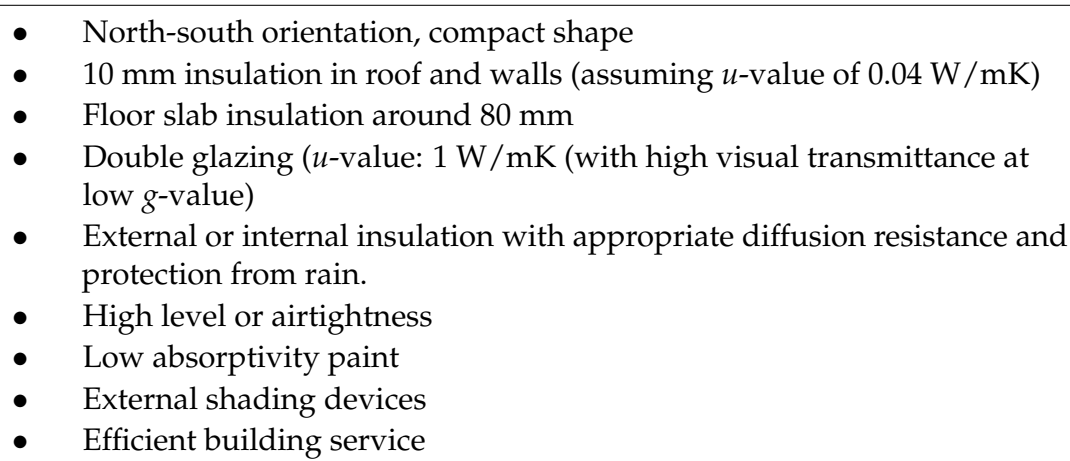 \\
\hline
\end{tabular}


A number of buildings (residential and non-residential) are already certified as passive buildings by the Passive House Institute. In Indonesia, there is only one certified passive building, an administrative office building, located in Jakarta [19] (Figure 2). The u-values of the wall, roof and basement floor or floor slab are $0.32,0.11$ and $0.29 \mathrm{~W} / \mathrm{m}^{2} \mathrm{~K}$, respectively. The solar heat gain of the window glazing is 0.3 , and the $\mathrm{u}$-value is $1.1 \mathrm{~W} / \mathrm{m}^{2} \mathrm{~K}$. The airtightness is $n_{50}: 0.4 / \mathrm{h}$. The important element in reducing the high temperature is controlling ventilation, which works with heat exchangers, resulting in about $78 \%$ heat recovery. Another thing is that the building is surrounded by plants and water, which helps to provide a cool micro climate. No residential house has been certified in this country, and it has become a challenge with which this present research is trying to deal.
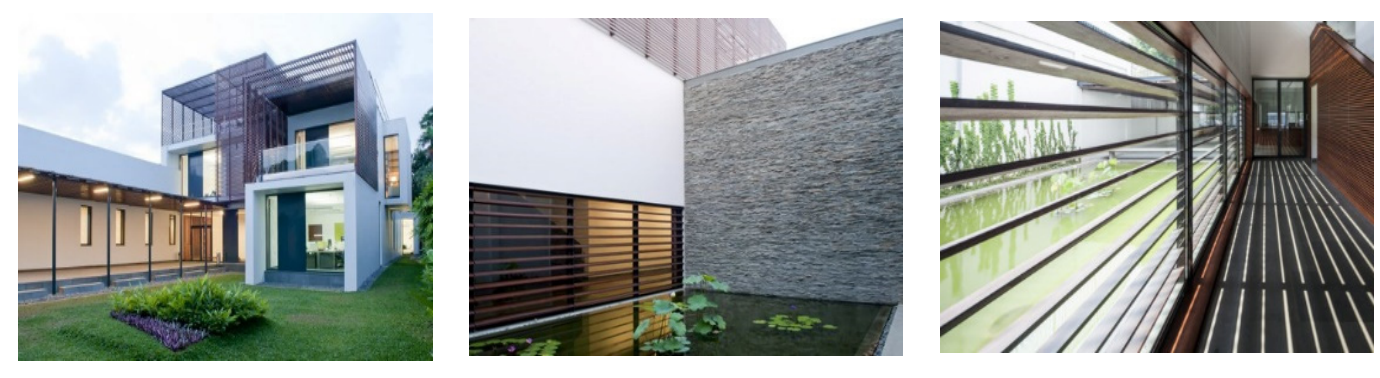

Figure 2. Passive office building in Jakarta [19].

\subsection{Adaptive Thermal Comfort}

Adaptive thermal comfort has recently gained much attention by researches in the thermal comfort field. Several adaptive models have been developed around the world (Table 3). The ASHRAE adaptive comfort model is the most well-known model based on the result from the project by ASHRAE RP-884, which collected data from around the world (with no climate classification) and analyzed the comfort model for an air conditioned and naturally-ventilated building separately. Unfortunately, this project lacks data from the mixed mode (hybrid) ventilation [20]. Humphreys and Nicol [21,22] got almost exact matches on the model of adaptive comfort by Humphreys in the 1970s by using data collected by De Dear and Brager [23]. Toe and Kubota also utilized the ASHRAE RP-884 database to develop an adaptive model for hot and humid climates by using mean daily temperatures, and they claim that the use of mean daily temperatures is better to predict the comfort temperature rather than the mean monthly outdoor temperature. An adaptive comfort model exclusively for hot and humid Southeast Asia was developed by Nguyen et al. [24] from 11 field studies in Singapore, Thailand, Malaysia, China and the Philippines. Indraganti et al. [25] developed an adaptive model for hot and humid offices in India using running mean daily temperature.

An initial step in the development of comfort temperature standards in Indonesia was done by Karyono, resulting in a Predictive Comfort Temperature (PCT), which can be applied for outdoor temperature between 24 and $29^{\circ} \mathrm{C}$ [26]. An advantage of this comfort model is that it was based on a field survey combined from mixed mode buildings in Indonesia, which the author claimed reflects the outdoor daily temperature, rather than the model derived from only the natural ventilation, as developed by Humphreys. However, from the author's perspective, this combination of mixed mode buildings to develop an adaptive comfort in Indonesia will give an advantage, because the occupants who live in naturally-ventilated houses mostly have to work in an office or study in a classroom that now tends to have an air conditioner. They are exposed to the air conditioned room for about eight hours a day, and when they go home, they have to adapt to a house that is ventilated naturally. This number of hours will affect the comfort perception/comfort temperature when they are at home. That is why, as a previous step of this present research, Santy adopted the PCT model with extending the range of outdoor temperatures by a field study in a city in Indonesia (Depok). Thus, further investigation of the exact time exposed to air conditioning, which affects comfort temperature, 
is suggested. Based on this field study, a Predictive Comfort Temperature upgrade (PCTu) was developed, which can be applied at an outdoor temperature between 24 and $30.8^{\circ} \mathrm{C}$.

In Figure 3, the adaptive models by Nicol and Humphreys (when the outdoor temperature is above $20^{\circ} \mathrm{C}$ ), Toe and Kubota, Indraganti and Nguyen predict higher comfort temperature compared to the ASHRAE standard. This fact is like stating that people in hot and humid countries, where they are exposed to an outdoor temperature usually above $20^{\circ} \mathrm{C}$, tend to have a higher preferred temperature than the other climates, which have lower outdoor temperatures. On the other hand, the adaptive models by Karyono and Santy are much closer to ASHRAE, and these lines predict the same comfort temperature as the outdoor temperature around $27^{\circ} \mathrm{C}$. The interesting point is that when the outdoor temperature is below $27^{\circ} \mathrm{C}$, these models predict lower than the ASHRAE standard, but in contrast, they predict higher when the outdoor temperature is above $27^{\circ} \mathrm{C}$.

Table 3. Several adaptive comfort model in the literature. PCT, Predictive Comfort Temperature.

\begin{tabular}{cccc}
\hline No. & Source & Equation & $\begin{array}{c}\text { Outdoor Temperature } \\
\text { Limitation }\end{array}$ \\
\hline 1 & ASHRAE 55-2004 [20] & $\mathrm{Tc}=0.31 \mathrm{~T}_{\mathrm{o}}^{*}+17.8$ & $10-33{ }^{\circ} \mathrm{C}$ \\
2 & Humphreys and Nicol [21,22] & $\mathrm{Tc}=0.54 \mathrm{~T}_{\mathrm{o}}{ }^{*}+13.5$ & $10-34^{\circ} \mathrm{C}$ \\
3 & Nguyen [24] & $\mathrm{TC}=0.341 \mathrm{~T}_{\mathrm{o}}^{*}+18.83$ & $26-34{ }^{\circ} \mathrm{C}$ \\
4 & Toe and Kubota [27,28] & $\mathrm{TC}=0.57 \mathrm{~T}_{\text {outdm }}{ }^{*}+13.8$ & $10-33{ }^{\circ} \mathrm{C}$ \\
5 & Indraganti et al. [29] & $\mathrm{Tc}=0.26 \mathrm{~T}_{\mathrm{rm}}+21.4$ & $24.5-35.5^{\circ} \mathrm{C}$ \\
6 & Karyono [26] & $\mathrm{PCT}=0.749 \mathrm{~T}_{\mathrm{d}}{ }^{*}+5.953$ & $24-29^{\circ} \mathrm{C}$ \\
7 & Santy [30] & $\mathrm{PCTu}=0.61 \mathrm{~T}_{\mathrm{d}}{ }^{\#}+9.69$ & $24-30.8^{\circ} \mathrm{C}$ \\
\hline
\end{tabular}

Notes: * For ASHRAE, Humphreys and Nicol, Nguyen, $\mathrm{T}_{\mathrm{o}}$ is mean monthly outdoor temperature; ${ }^{\#}$ for Toe and Kubota, Karyono and Santy, $\mathrm{T}_{\text {outdm }}$ and $\mathrm{T}_{\mathrm{d}}$ are mean daily outdoor temperature; for Indraganti, $\mathrm{T}_{\mathrm{rm}}$ is running mean outdoor temperature.

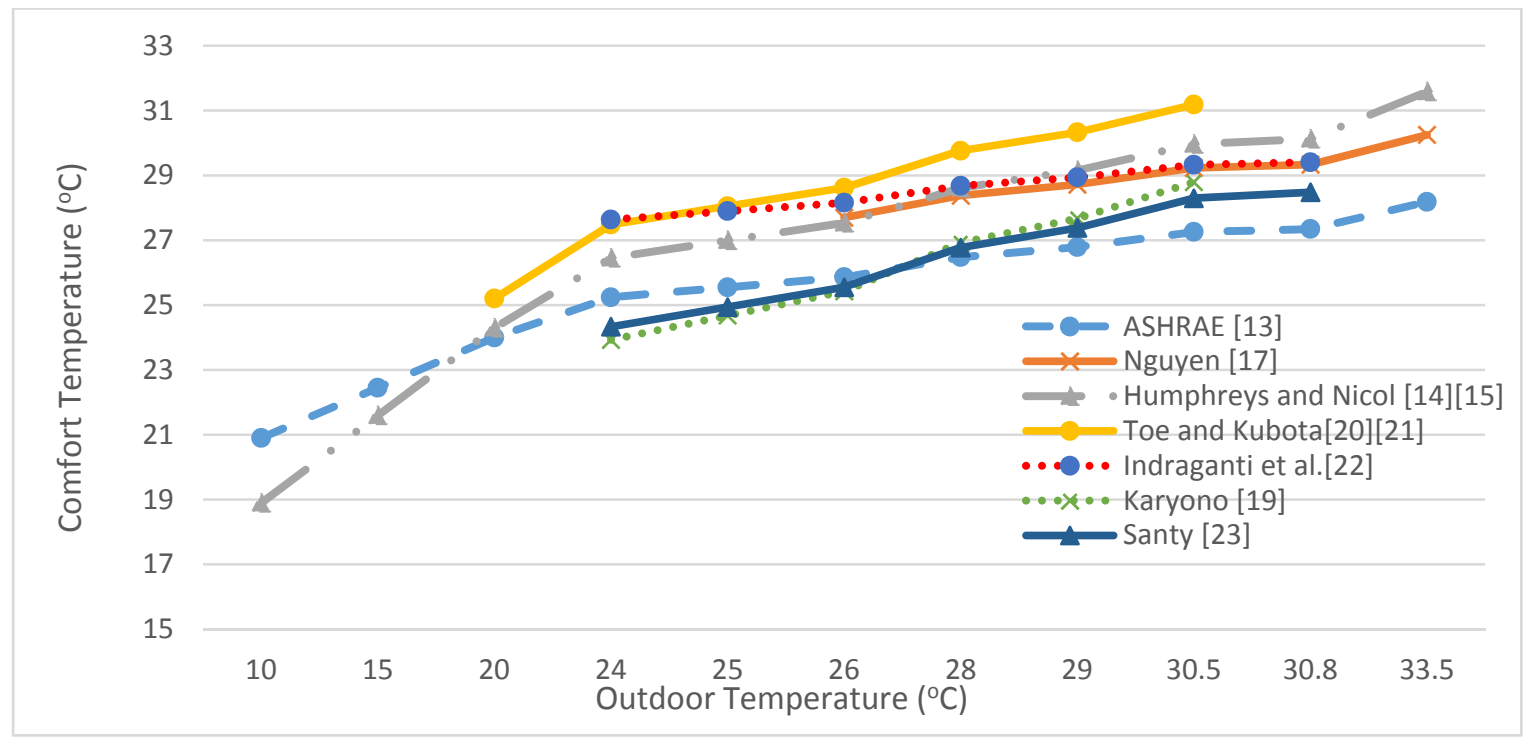

Figure 3. Comparison between adaptive comfort models in the literature.

\subsection{Thermal Comfort Research in Indonesia}

As is proven that an occupant's feeling of thermal comfort has a very close relationship with the climate where he/she lives, some previous research in Indonesia tried to investigate the relationship between the climate and an occupant's feeling of comfort in different types of buildings in Indonesia, including in residential houses. Research on thermal comfort in a residential house in Indonesia was done by Feriadi and Wong [31]. This study gathered 525 sets of data from naturally-ventilated houses in Yogyakarta. The main result of this study was that occupants staying in a naturally-ventilated house 
had a higher thermal comfort level than PMV had predicted. A possible reason for this finding was that the occupants had the freedom to modify the environment by opening windows or turning on fans, allowing them to compensate for the uncomfortable thermal conditions. Another result is that occupants prefer a cooler $\left(26^{\circ} \mathrm{C}\right)$ environment than the neutral temperature that was chosen $\left(29.2^{\circ} \mathrm{C}\right)$. This fact implies that thermal neutrality is affected by the historical experience of climate and also by the ability to modify the environment. This finding was in alignment with another study by Luo [32] in China, which concluded that personal control can lower thermal neutrality and expectation. Other research by Sujatmiko [33] observed the thermal neutrality, thermal acceptance and thermal preference in residential house occupants in Bandung, Semarang and Bekasi. Its results show that the thermal acceptability of about $80 \%$ is between $22.8^{\circ} \mathrm{C}$ and $30.2{ }^{\circ} \mathrm{C}$, but thermal neutrality is $27.3^{\circ} \mathrm{C}$ indoor dry bulb temperature (Tdb). This range of acceptability is quite high, and a possible reason for this is the significant temperature difference between Bandung $\left(17.4^{\circ} \mathrm{C}\right)$ and Semarang $\left(23.1^{\circ} \mathrm{C}\right)$. Being located in a high altitude area makes the average temperature in Bandung lower than other cities in Indonesia. Research by Santy [30] proposed a Predictive Comfort Temperature upgrade (PCTu) for Indonesia, which upgraded the research result by Karyono [26] due to a wider range of mean outdoor temperatures. This prediction of comfort temperature is very important in order to set the comfort zone in Indonesia, as until recently, Indonesia still adopted a standard [26,34] based on the heat balance approach developed by Fanger, which does not adequately describe comfortable conditions for people in tropical climate countries [22].

\section{Research Methodology}

This paper exposes the pre-design stage in the development of a passive house standard for residential buildings in Indonesia that serves both thermal comfort and energy efficiency. The concept of a passive house in this research is defined as a house that does not need the application of a mechanical HVAC system for heating or cooling purposes. The city of Jakarta was chosen for deep analysis, which, based on previous research, can represent almost all of the Indonesian regions in terms of temperature and relative humidity. The Olgyay Bioclimatic chart, Givoni-Milne Bioclimatic chart and the Mahoney Table were used to analyze the climatic characteristics of the selected city. These three tools are well known and are believed to be appropriate tools for the investigation of a strategy for designing buildings that correspond to the climate. Some passive design strategies were proposed based on the analysis. It should be noted that the Szokolay Bioclimatic chart will not be used in this research because the relative humidity is more than $90 \%$ for almost half of the year.

\subsection{Olgyay Bioclimatic Chart}

The Olgyay Bioclimatic chart is one of the tools widely employed in the pre-design stage of building design by an architect [6,35-38]. In this stage, historical data related to temperature and relative humidity are plotted in the chart. In this chart, the comfort zone for different types of built environments can be discovered. Corrective measures needed for factors, such as wind, solar radiation and shading, can also be known for every plotted fall over the comfort zone.

\subsection{Givoni-Milne Bioclimatic Chart}

The Givoni-Milne Bioclimatic chart is developed based on the psychometric chart. The psychometric chart displays the relation of several climate parameters, including dry bulb temperature, wet bulb temperature, dew point temperature, relative humidity, humidity ratio (moisture content), specific volume and enthalpy. Any psychrometric chart is valid at a certain pressure of air that relates to the height above sea level. By plotting two parameters in this chart, five other values may be obtained easily. By plotting the climate, the appropriate strategy is able to be selected in accordance. Givoni-Milne proposes seven passive strategies in this chart, which includes heating, internal gains, natural ventilation, high mass cooling, high mass cooling with night ventilation, evaporative cooling and shading devices. 


\subsection{Mahoney Table}

The Mahoney Tables are a set of tables to analyze climates (including temperature, humidity, precipitation) in order to provide building design recommendations for a given location [39]. In the first step, the minimum and maximum temperatures should be obtained in order to know the temperature difference for each month. The minimum, maximum and average relative humidity is also needed to classify the humidity group in the location. There are four classifications of relative humidity: 1 (below 30\%), $2(30 \%-50 \%), 3(50 \%-70 \%)$ and 4 (above $70 \%$ ) (Table 4$)$. The monthly level of rainfall is required in the last stage to reveal the necessity for heavy rain protection in a building design. The next step is to diagnose thermal stress during both the day and night based on the monthly minimum and maximum temperatures. There are three classes of thermal stress, $\mathrm{Hot}(\mathrm{H}$, if the mean temperature is above the limit), Comfortable $(\mathrm{O}$, if the mean temperature is within the limit) and Cold ( $\mathrm{C}$, if the mean temperature is below the limit). The comfort limit itself depends on the Annual Mean Temperature (AMT) and humidity group. The AMT is the average of the highest monthly mean maximum and the lowest mean minimum temperatures [39]. The total value of thermal stress occurring during day and night is crucial to determine the humidity and arid indicator. The humidity indicators are H1 (when the temperature is above the comfort limit and humidity Groups 2-4), H2 (when the temperature is within the comfort limit and humidity Group 4) and H3 (when rainfall exceeds $200 \mathrm{~mm} / \mathrm{month}$ ). The arid indicators are 1 (when the diurnal range is $10^{\circ} \mathrm{C}$ or more, and humidity Groups $1-3$ ), 2 (when the temperature is above the comfort limit and humidity Groups 1-2), 3 (when day thermal stress is C). In the final step, the design recommendation administers alternatives for layout, spacing, air movement, openings, walls and floors, roofs and outdoor sleeping. The alternatives will be selected based on the total points of the humid and arid indicators obtained before.

Table 4. Humidity group.

\begin{tabular}{cc}
\hline Group & Relative Humidity \\
\hline 1 & Below 30\% \\
2 & $30 \%-50 \%$ \\
3 & $50 \%-70 \%$ \\
4 & Above 70\% \\
\hline
\end{tabular}

\subsection{Energy Simulation}

Energy simulation is used to investigate the energy performance within a building. There are several building energy performance programs, such as Energyplus, Equest, Ecotect and others. Investigation of indoor thermal condition, such as temperature and humidity, can be done with the input of building design, building material and its properties, occupancy of the building, internal gains within the building, weather data and other parameters. This present research utilized the Energyplus 8.5 simulation program to investigate the effectiveness of the passive strategy proposed by the bioclimatic analysis.

\section{Case Study Data}

Table 5 presents the monthly mean temperature in Jakarta and shows that the temperature difference throughout the year is not significant, with the monthly mean min and max being $20^{\circ} \mathrm{C}$ and $34{ }^{\circ} \mathrm{C}$, respectively, and the result on AMT being $27^{\circ} \mathrm{C}$. Relative humidity ranges between $32 \%$ and 96\% (Table 6) and, based on the classification in Table 4, is relatively high, as it falls under Groups 3 and 4 based on the classification. Table 7 exposes the monthly level of rainfall for each month and resulted in a total of $2528 \mathrm{~mm}$ rainfall/year. 
Table 5. Monthly mean air temperature $\left({ }^{\circ} \mathrm{C}\right)$.

\begin{tabular}{ccccccccccccc}
\hline Month & J & F & M & A & M & J & J & A & S & O & N & D \\
\hline Monthly mean max & 30 & 30 & 31 & 31 & 32 & 32 & 32 & 32 & 34 & 34 & 33 & 31 \\
Monthly mean min & 23 & 22 & 22 & 22 & 21 & 20 & 20 & 20 & 20 & 21 & 22 & 23 \\
Monthly mean range & 7 & 8 & 9 & 9 & 11 & 12 & 12 & 12 & 14 & 13 & 11 & 8 \\
\hline
\end{tabular}

Table 6. Monthly mean relative humidity (\%).

\begin{tabular}{ccccccccccccc}
\hline Month & J & F & M & A & M & J & J & A & S & O & N & D \\
\hline Monthly mean max a.m. & 96 & 95 & 93 & 94 & 91 & 90 & 89 & 87 & 85 & 86 & 90 & 92 \\
Monthly mean min p.m. & 64 & 62 & 61 & 57 & 52 & 46 & 45 & 41 & 32 & 33 & 43 & 57 \\
Average & 80 & 78 & 77 & 75 & 72 & 68 & 67 & 64 & 59 & 60 & 66 & 74 \\
Humidity group & 4 & 4 & 4 & 4 & 4 & 3 & 3 & 3 & 3 & 3 & 3 & 4 \\
\hline
\end{tabular}

Table 7. Monthly amount of rainfall.

\begin{tabular}{cccccccccccccc}
\hline Month & J & F & M & A & M & J & J & A & S & O & N & D & Total \\
\hline Rain fall $(\mathrm{mm})$ & 622 & 147 & 184 & 204 & 101 & 257 & 257 & 61 & 50 & 110 & 197 & 339 & 2528 \\
\hline
\end{tabular}

\section{Result of Bioclimatic Analysis}

\subsection{Olgyay Bioclimatic Chart for Jakarta}

Figure 4 highlights the Bioclimatic chart for Jakarta, and the line represents the mean monthly minimum and maximum temperatures with the corresponding relative humidity in a year (twelve months). For almost the entire year, the minimum value of temperature resides in the comfort zone, while the maximum value is lying outside the area. This indicates a muggy condition for every month due to the high levels of temperature and humidity. The data demonstrate a need for a high level of wind to counteract vapor pressure. The recommended wind velocities suggested by Olgyay are up to $700 \mathrm{ft} / \mathrm{min}$ or equal to $3.5 \mathrm{~m} / \mathrm{s}$ for temperatures up to $32{ }^{\circ} \mathrm{C}$ and humidity up to $90 \%$. As the wind speed in most parts of Indonesia is greater than $3 \mathrm{~m} / \mathrm{s}$; it is deemed sufficient to address the high level of humidity. Furthermore, all of the data fall above the shading line, which implies that a shading device is a crucial element that must be present in a house in order to reduce solar gain entering the building. Further research is needed to examine the different type, size and appropriate locations to install shading devices.

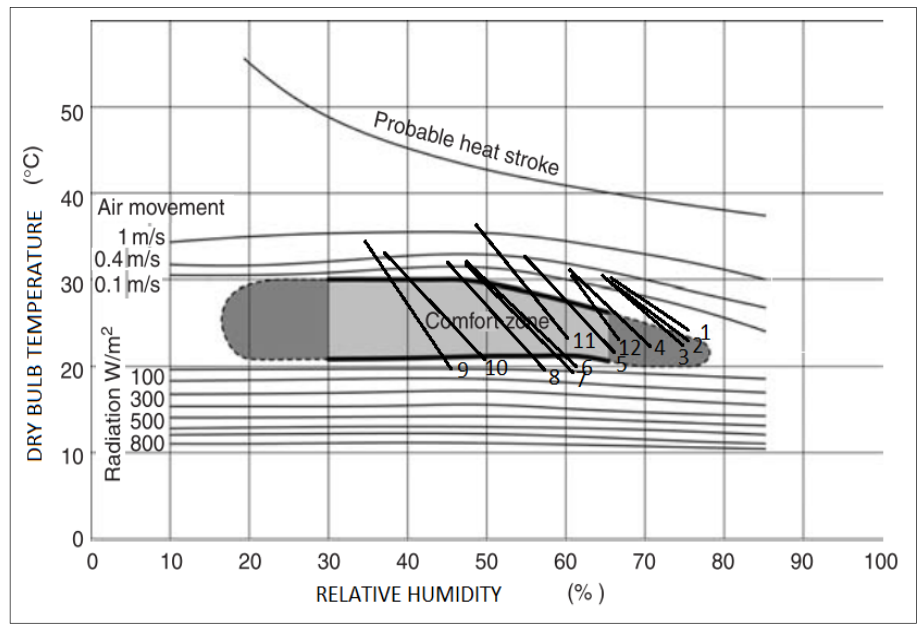

Figure 4. Olgyay Bioclimatic chart of Jakarta. 
With its tropical climate, Indonesia has a relatively high temperature and level of humidity. The high level of temperature is due to its geographical location, which passes through the Equator, an area where the Sun passes closest to Earth; whereas, the high level of humid conditions is because the form of Indonesia is an archipelago, which is surrounded by the sea. The high temperatures caused by strong solar radiation make the sea evaporate and increase the humidity levels in the mainland. In this hot and humid environment, psychological parameters, such as heart rate, body temperature and sweat production, are greater than in a relatively cooler environment. The sweating process increases in order to cool and release heat from the body [40]. In a severe and prolonged sweat, the amount of water and salt in the body might be lost in a considerable quantity, which can lead to cramps, headaches and general weakness.

\subsection{Givoni-Milne Bioclimatic Chart for Jakarta}

Regarding the comfort zone in the Givoni-Milne Bioclimatic chart, the original comfort boundary was based on research conducted in the United States, Europe and Israel, and it is believed that it should be acclimated for use in regions with a hot and humid climate [41]. As described previously, the latest research by Santy et al. [30] investigated the comfort temperature to be applied for Indonesia by upgrading the research result by Karyono [26], which resulted in the Predictive Comfort Temperature upgrade (PCTu) (Equation (1)). According to PCTu $\left(R^{2}\right.$ is 0.38 and significant at the 95\% confidence level), the predictive comfort temperature in Jakarta with a mean outdoor temperature of $28.2{ }^{\circ} \mathrm{C}$ is $26.8 \pm 1.5^{\circ} \mathrm{C}(80 \%$ acceptability). Thus, for the development of a Givoni-Milne Bioclimatic chart of Jakarta, the comfort zone will be expanded to this new comfort boundary. Since this bioclimatic chart represents the condition of outdoor air and while the comfort temperature defined by Santy et al. is indoor air, a calculation is needed to know the outdoor temperature capable of producing indoor comfort. Based on PCTu, the mean outdoor temperature of $25.5-30.5{ }^{\circ} \mathrm{C}$ will provide indoor comfort. As Equation (1) only determines comfort temperature, the humidity level of comfort is adopted from the Indonesian standard SNI 6390:2011, which is $60 \% \pm 5 \%$ of relative humidity.

$$
\text { PCTu }=0.61 \mathrm{Td}+9.69
$$

$T d$ : mean monthly outdoor temperature

PCTu: predictive comfort temperature upgrade

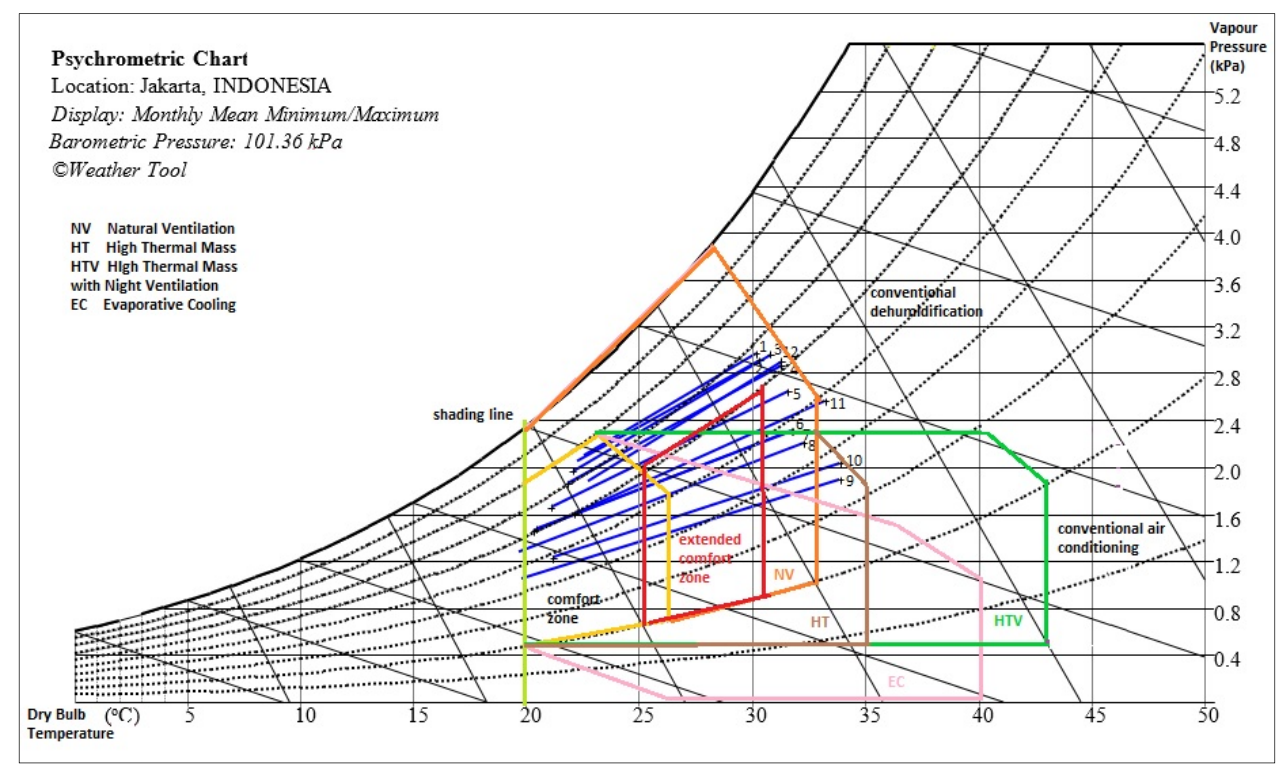

Figure 5. Givoni-Milne Bioclimatic chart of Jakarta. 
The Givoni-Milne Bioclimatic chart of Jakarta was created by plotting the temperature and relative humidity. As shown in Figure 5, natural ventilation is believed to be the easiest and most inexpensive method of a passive strategy in hot and humid areas for every month. It aims to attain an adequate level of fresh air by changing the outside and inside air through an opening. Moreover, ventilation will escalate the rate of evaporative and sensible heat loss from the body [42]. Wind direction, the area of penetration, the size of the inlet and outlet, the volume of the room, shading devices, fly screen and internal partitions are parameters that should be considered carefully in order to obtain a pleasant level of ventilation [43]. The chart also recommends shading devices because the temperature is greater than $20{ }^{\circ} \mathrm{C}$. The shading device is an alternative to reduce the incidents of solar radiation. A good shading strategy can lower cooling energy loads up to $10 \%-20 \%$. Only two months (September and October) need a high thermal mass to achieve comfort.

The previous research by Azri et al. [10] that utilized this Givoni-Milne Bioclimatic chart was undertaken in Muscat, Oman. Although the research concludes that this city has a hot and humid climate (based on temperature and humidity level), it also shows that the resulting gains from the Givoni-Milne Bioclimatic chart are not perfectly the same. In the result presented, mechanical dehumidification and high thermal mass with night ventilation are required for the hot and humid months (June and July) as the temperature reaches up to $40{ }^{\circ} \mathrm{C}$. Some of the data also fall in the high thermal mass boundary area, as well as in Jakarta. The differences between the results are most likely caused by differences in the comfort zones defined by the study. A study by Azri et al. [10] used a comfort zone defined by ASHRAE, while the present study used a comfort zone defined by Santy et al. [30], which was adapted for a tropical hot and humid region. Furthermore, a high thermal mass building envelope application in a hot and humid climate has been investigated previously [44-46]. Cheng et al. [44] investigated the effect of thermal mass on indoor temperatures in Hong Kong. The experiment showed that the application of high thermal mass is not always useful and depends on the occupancy pattern. In a building with a high thermal mass, the thermal mass will cover up the increase in indoor temperature, but the stored heat in the building envelope will be radiated back at night. This phenomenon will increase the probability of a high temperature and result in discomfort during night time. Thus, in a residential building with low occupancy during the day, but high occupancy during the night (family members have to work during the day and stay at home during the night), this option will not be appropriate. Zhou et al. [45] studied the effect of an adiabatic wall and six different configurations of external and internal mass on indoor temperature. The fluctuation of indoor air temperature is better and the time lag is smaller for walls with external insulation than those with external insulation. The research also developed a model to predict the indoor air temperature and design the amount of thermal mass that need to be addressed for certain characteristics of a naturally-ventilated building. The latest research by Motamedi and Akhavan [46] conducted a simulation analysis by employing the Energy Plus simulation program to find out the effect of thermal mass on cooling and heating energy loads in a small office with an HVAC system in Austin, Texas. The result indicated a savings for the cooling load for a high wall model, which consumes 1015, $85 \mathrm{kWh}$ less than a low mass wall model. This result is relatively different from Cheng et al. [44], as previously described. Thus, it can be concluded that the usage of thermal mass in a hot and humid country is dependent on the type of building, whether it has natural ventilation or an HVAC system, and also the schedule of building occupancy. Furthermore, the simulation of energy performance in a building will be useful in order to seek the effectiveness of thermal mass in a specific climate.

\subsection{Mahoney Tables for Jakarta}

Based on the comfort limit presented in Table 8, the temperature diagnosis table exposes that the thermal stress during the day throughout the year is $\mathrm{H}(\mathrm{Hot})$, which means that the temperature is always above the comfort limit. At night, from December-March, the thermal stress is $\mathrm{H}$ (Hot), but from May-November, it is O (Comfortable) (Table 9). This result will greatly affect the humid 
and arid indicators. Table 10 provides the determination of the humid and arid indicators, and the result in Table 11 points out that the indicator for Jakarta is H1 (six months), implying the essential need for air movement to achieve a level of thermal comfort due to high temperature and humidity during the day and night. From June-November, even though the thermal stress of the day is hot, the humidity is in Group 3, and the temperature difference is more than $10^{\circ} \mathrm{C}$, which needs thermal storage for this condition (A1). In addition, rain protection is also required for five months of the year (H3). There is no need for space for outdoor sleeping because the humidity level is quite high (Groups 3 and 4). Rain protection is also necessary due to the high level of rainfall. Table 12 presents the design recommendation for layout, spacing, air movement, openings, walls and floors, roofs and outdoor sleeping and the result is summarized in Table 13.

Table 8. Comfort limit. AMT, Annual Mean Temperature.

\begin{tabular}{ccccccc}
\hline AMT & \multicolumn{2}{c}{$>\mathbf{2 0}{ }^{\circ} \mathbf{C}$} & \multicolumn{2}{c}{$\mathbf{1 5 - 2 0}{ }^{\circ} \mathbf{C}$} & \multicolumn{2}{c}{$<\mathbf{1 5}{ }^{\circ} \mathbf{C}$} \\
\hline Humidity Group & Day & Night & Day & Night & Day & Night \\
\hline 1 & $26-34$ & $17-25$ & $23-32$ & $14-23$ & $21-30$ & $12-21$ \\
2 & $25-31$ & $17-24$ & $22-30$ & $14-22$ & $20-27$ & $12-20$ \\
3 & $23-29$ & $17-23$ & $21-28$ & $14-21$ & $19-26$ & $12-19$ \\
4 & $22-27$ & $17-21$ & $20-25$ & $14-20$ & $18-24$ & $12-18$ \\
\hline
\end{tabular}

Table 9. Temperature diagnosis.

\begin{tabular}{cccccccccccccc}
\hline Month & J & F & M & A & M & J & J & A & S & O & N & D & AMT \\
\hline Monthly mean max $\left({ }^{\circ} \mathrm{C}\right)$ & 30 & 30 & 31 & 31 & 32 & 32 & 32 & 32 & 34 & 34 & 33 & 31 & 27 \\
Day comfort upper $\left({ }^{\circ} \mathrm{C}\right)$ & 27 & 27 & 27 & 27 & 27 & 29 & 29 & 29 & 29 & 29 & 29 & 27 & \\
Day comfort lower $\left({ }^{\circ} \mathrm{C}\right)$ & 22 & 22 & 22 & 22 & 22 & 23 & 23 & 23 & 23 & 23 & 23 & 22 & \\
Monthly mean min $\left({ }^{\circ} \mathrm{C}\right)$ & 23 & 22 & 22 & 22 & 21 & 20 & 20 & 20 & 20 & 21 & 22 & 23 & \\
Night comfort upper $\left({ }^{\circ} \mathrm{C}\right)$ & 21 & 21 & 21 & 21 & 21 & 23 & 23 & 23 & 23 & 23 & 23 & 21 & \\
Night comfort lower $\left({ }^{\circ} \mathrm{C}\right)$ & 17 & 17 & 17 & 17 & 17 & 17 & 17 & 17 & 17 & 17 & 17 & 17 & \\
Thermal stress day & $\mathrm{H}$ & $\mathrm{H}$ & $\mathrm{H}$ & $\mathrm{H}$ & $\mathrm{H}$ & $\mathrm{H}$ & $\mathrm{H}$ & $\mathrm{H}$ & $\mathrm{H}$ & $\mathrm{H}$ & $\mathrm{H}$ & $\mathrm{H}$ & \\
Thermal stress night & $\mathrm{H}$ & $\mathrm{H}$ & $\mathrm{H}$ & $\mathrm{H}$ & $\mathrm{O}$ & $\mathrm{O}$ & $\mathrm{O}$ & $\mathrm{O}$ & $\mathrm{O}$ & $\mathrm{O}$ & $\mathrm{O}$ & $\mathrm{H}$ & \\
\hline
\end{tabular}

Table 10. Determination of humid and arid indicator. H, Hot; O, Comfortable; C, Cold.

\begin{tabular}{|c|c|c|c|c|c|}
\hline \multirow[t]{2}{*}{ Indicator } & \multicolumn{2}{|c|}{$\begin{array}{l}\text { Thermal } \\
\text { Stress }\end{array}$} & \multirow[t]{2}{*}{$\begin{array}{l}\text { Monthly } \\
\text { Rainfall }\end{array}$} & \multirow[t]{2}{*}{$\begin{array}{l}\text { Humidity } \\
\text { Group }\end{array}$} & \multirow[t]{2}{*}{$\begin{array}{c}\text { Monthly Mean } \\
\text { Temperature Range }\end{array}$} \\
\hline & Day & Night & & & \\
\hline \multirow{2}{*}{ H1(Air movement essential) } & $\mathrm{H}$ & & & 4 & \\
\hline & $\mathrm{H}$ & & & 2,3 & $<10^{\circ} \mathrm{C}$ \\
\hline H2 (Air movement desirable) & $\mathrm{O}$ & & & 4 & \\
\hline H3 (Rain protection) & \multicolumn{5}{|c|}{ Over $200 \mathrm{~mm} /$ month } \\
\hline A1 (Thermal storage) & & & & $1,2,3$ & $>10^{\circ} \mathrm{C}$ \\
\hline \multirow{2}{*}{ A2 (Outdoor sleeping) } & & $\mathrm{H}$ & & 1,2 & \\
\hline & $\mathrm{H}$ & $\mathrm{O}$ & & 1,2 & $>10^{\circ} \mathrm{C}$ \\
\hline A3 (Cold season problem) & $\mathrm{C}$ & & & & \\
\hline
\end{tabular}

Table 11. Humid and arid indicator.

\begin{tabular}{|c|c|c|c|c|c|c|c|c|c|c|c|c|c|}
\hline Indicator & $\mathbf{J}$ & $\mathbf{F}$ & $\mathbf{M}$ & A & $\mathbf{M}$ & $\mathbf{J}$ & $\mathbf{J}$ & $\mathbf{A}$ & $\mathrm{S}$ & $\mathbf{O}$ & $\mathbf{N}$ & D & Total \\
\hline $\begin{array}{l}\text { H1(Air movement essential) } \\
\text { H2 (Air movement desirable) }\end{array}$ & $\sqrt{ }$ & $\sqrt{ }$ & $\sqrt{ }$ & $\sqrt{ }$ & $\sqrt{ }$ & & & & & & & $\sqrt{ }$ & 6 \\
\hline H3 (Rain Protection) & $\sqrt{ }$ & & & $\sqrt{ }$ & & $\sqrt{ }$ & $\sqrt{ }$ & & & & & $\sqrt{ }$ & 5 \\
\hline A1 (Thermal storage) & & & & & & $\sqrt{ }$ & $\sqrt{ }$ & $\sqrt{ }$ & $\sqrt{ }$ & $\sqrt{ }$ & $\sqrt{ }$ & & 6 \\
\hline A2 (Outdoor sleeping) & & & & & & & & & & & & & \\
\hline A3 (Cold season problem) & & & & & & & & & & & & & \\
\hline
\end{tabular}


Table 12. Design recommendation.

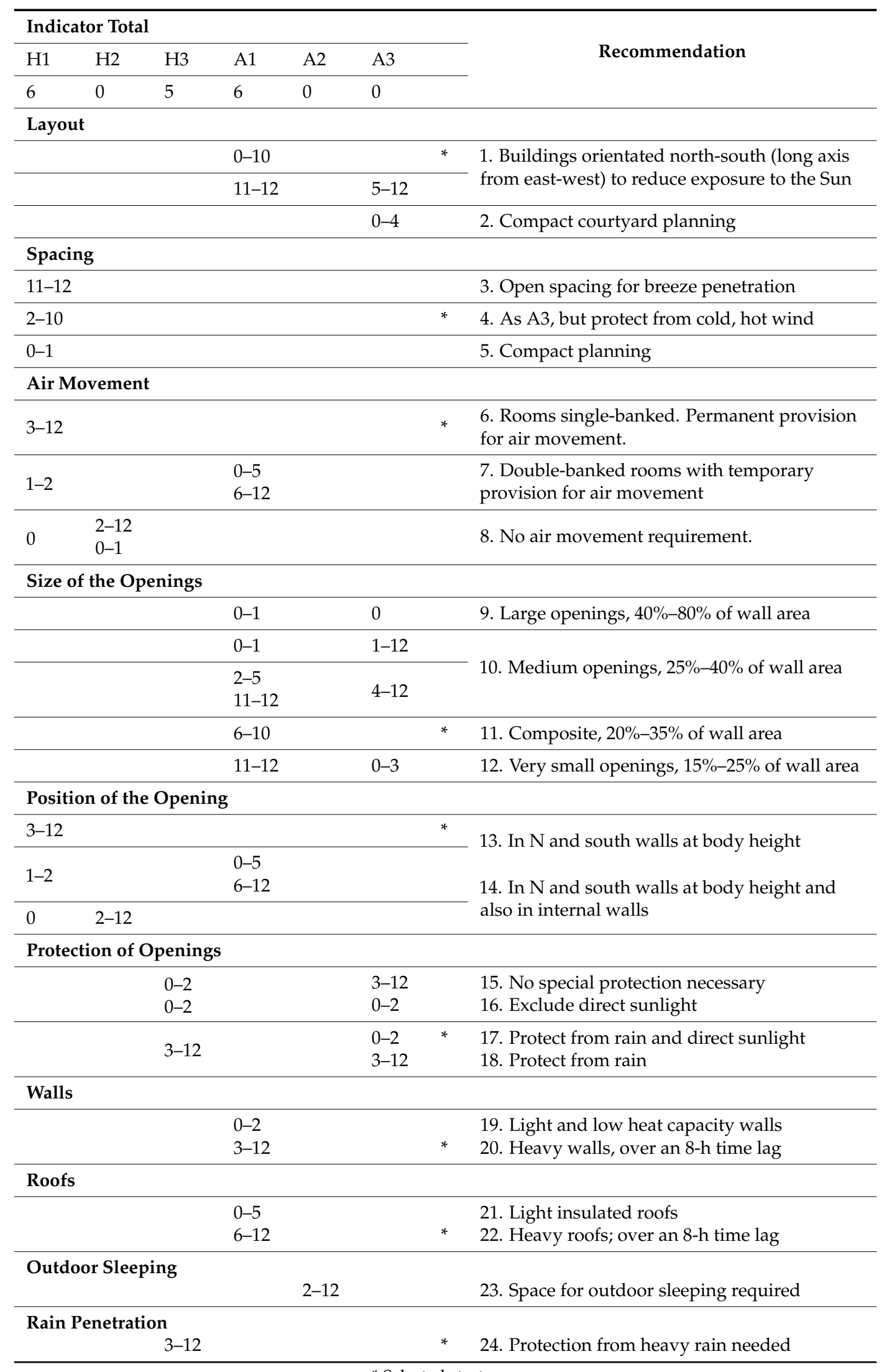


Table 13. Recommendation for building design in Jakarta.

\begin{tabular}{ll}
\hline \multicolumn{1}{c}{ Element } & \multicolumn{1}{c}{ Recommendation } \\
\hline Layout & $\begin{array}{l}\text { Buildings orientated from north-south (long axis from east-west) } \\
\text { to reduce exposure to the Sun }\end{array}$ \\
\hline Spacing & Open spacing for protection from hot wind \\
Air movement & Rooms single-banked. Permanent provision for air movement. \\
Size of openings & Composite, 20\%-35\% of wall area \\
Position of openings & In N and S walls at body height \\
Protection of opening & Protect from rain and direct sunlight \\
Walls and floors & Heavy walls, over an 8-h time lag \\
Roofs & Heavy roofs, over an 8-h time lag \\
Outdoor sleeping & Space for outdoor sleeping is not needed \\
Protection from heavy rain & Protection from heavy rain is needed \\
\hline
\end{tabular}

\section{Summary of Bioclimatic Analysis}

Three tools were utilized to investigate climate conditions in Jakarta, the Olgyay Bioclimatic Chart, the Givoni-Milne Bioclimatic Chart and the Mahoney Table. Table 14 summarizes the design recommendations obtained by each tool.

Table 14. Summary of design recommendations.

\begin{tabular}{|c|c|}
\hline Olgyay & Wind Penetration and Shading Devices \\
\hline Givoni-Milne & Natural ventilation and shading device \\
\hline Mahoney Table & $\begin{array}{l}\text { Buildings oriented north-south (long axis from east to west) } \\
\text { Open spacing for protection from hot wind } \\
\text { Single banked room for permanent provision of air } \\
\text { Composite openings, } 20 \%-35 \% \text { of wall area at body height } \\
\text { Position of windows in north and south walls } \\
\text { Protection of the openings from rain and direct sunlight } \\
\text { Heavy walls with more than an } 8 \text {-h time lag } \\
\text { Heavy roof with more than an } 8 \text {-h time lag } \\
\text { Protection from heavy rain }\end{array}$ \\
\hline
\end{tabular}

\subsection{Natural Ventilation for Wind Penetration}

Climate analysis using the Olgyay and Givoni-Milne Bioclimatic charts recommends almost the same, the utilization of wind penetration by natural ventilation. In addition, the Mahoney Table also suggests a matching idea, open space for protection against hot wind. The Mahoney Table gives an additional recommendation regarding the size and position of windows, which cover $20 \%-35 \%$ of the wall areas in the north and south walls at body height. This recommendation is believed to be the solution for high levels of temperature and humidity in hot and humid and tropical climates. Moreover, the Mahoney Table endorses the installation of additional protection devices from rain and direct sunlight.

\subsection{Shading Devices}

A shading device is usually needed whenever the outdoor air temperature exceeds the lower limit of the comfort zone, which is $20^{\circ} \mathrm{C}$ [42]. The shading devices might be installed inside and/or outside the building. Neighboring landforms, structures or vegetation, overhang/louvers or texture facades are the options for external shading devices. Shading by vegetation is considered to be an effective way to reduce the ambient level of hot air, which usually occurs in hot and humid climates. This is because the leaves absorb the solar heat for photosynthesis [43]. On the other hand, a movable opaque shade, such as roller blinds or curtains, is a possible alternative for internal shading devices. Thus, this shading has a probability of eliminating the view to the outside and a hindering air movement. 
Furthermore, this shading device will have a role also in protecting the opening from solar penetration and rain. For that reason, the geometry and placement of the overhang and louvers should be planned with care. The overhangs on south-oriented windows will give protection from a high altitude window.

In order to know the requirement for shading, a Sun path diagram might be used to reveal the number of hours the Sun will penetrate the building envelope. The stereographic Sun path diagram of Jakarta is shown in Figure 6. The stereographic Sun path diagram reveals the solar altitude and azimuth throughout the day for a given position on Earth. The shading coefficient will also be discovered by the Sun path diagram. The shading coefficient is defined as the fraction of solar radiation transmitted by a specified device. Appropriate shading devices should strive to obtain an effective shading coefficient. Table 15 exposes the shading coefficient needed in a north-oriented building in Jakarta. It is shown that the average shading coefficient needed is in the range between $36 \%$ and $64 \%$ annually for buildings oriented in a northern direction.

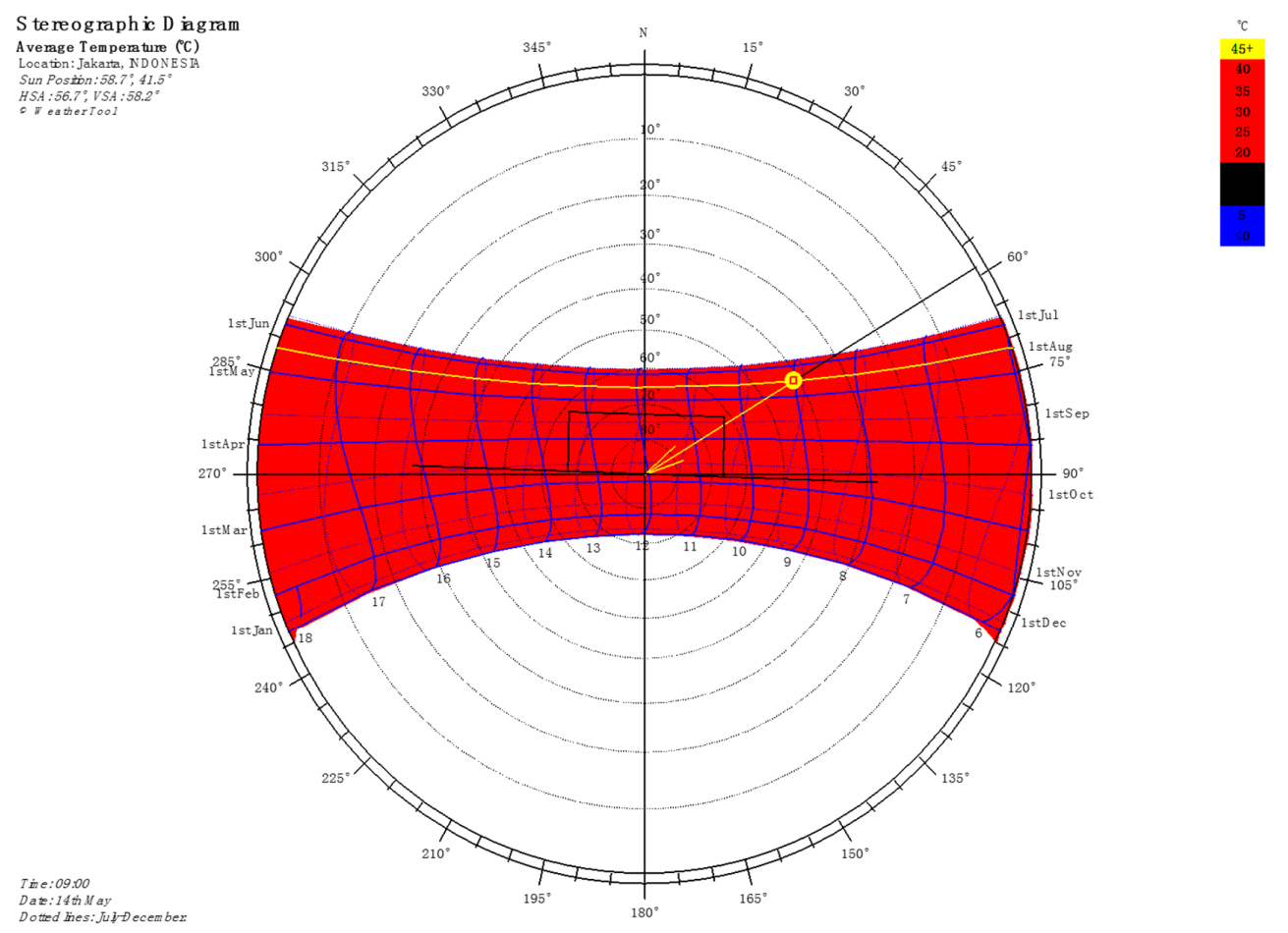

Figure 6. Sun path diagram of Jakarta (Autodesk Ecotect Weather Tool Software) [47].

Table 15. Effective shading coefficient (SC) in a south-facing building in Jakarta (Autodesk Ecotect Solar Tool Software 2011) [48].

\begin{tabular}{cccc}
\hline Month & Avg. SC & Max SC & Min SC \\
\hline January & Behind & & \\
February & Behind & & \\
March & $63.2 \%$ & $100 \%$ & $0 \%$ \\
April & $63.5 \%$ & $100 \%$ & $0 \%$ \\
May & $62.3 \%$ & $100 \%$ & $0 \%$ \\
June & $64.8 \%$ & $100 \%$ & $0 \%$ \\
July & $65.5 \%$ & $100 \%$ & $0 \%$ \\
August & $62.9 \%$ & $100 \%$ & $0 \%$ \\
September & $70.5 \%$ & $100 \%$ & $14 \%$ \\
October & Behind & & \\
November & Behind & & \\
December & Behind & & \\
Annual & $37.70 \%$ & $58.30 \%$ & $42.80 \%$ \\
\hline
\end{tabular}




\subsection{Building Orientation}

The building orientation offered by the Mahoney Table is north-south (long axis from east to west). This orientation is due to high solar penetration coming from the east in the morning and the west in the evening, which needs to be avoided. However, the building orientation itself largely depends on the surrounding environment, which occasionally limits such a choice.

\subsection{Wall and Roof}

Heavy walls and roofs will help to protect the building from heating from solar penetration. Thus, as discussed previously, the occupancy schedule should be a factor of concern in choosing the walls and roofs especially in relation to the time lag of re-radiating the heat from the building material. As the Mahoney Table proposed a heavy wall with a high thermal mass, the Givoni-Milne Bioclimatic chart did not recommend a high thermal mass material as the passive strategy. Furthermore, several research works $[49,50]$ found that lightweight material for the wall is preferable in tropical climates, as it will release the heat faster than the heavy weight material. A simulation process is better to investigate which is better (heavy weight or light wall) to be applied in Indonesia.

\section{Energy Simulation}

Energy conservation issues are beginning to draw the attention of researchers, along with an increase on the demand for and consumption of energy itself. The environmental impact including climate change caused by energy production has also encouraged the researcher to explore more and find an appropriate solution for these problems. In Indonesia, as a tropical climate country, the electricity consumption for cooling a house especially by an air conditioner consumed more than $35 \%$ of total consumption and ranks first among the other consumptions [51]. Katili et al. [52] show that the electricity consumption by an air conditioner is about $56 \%$ of total electricity consumption in Southeast Asia. It is a challenge for the researcher to decrease this number in order to minimize the environmental impact due to the exhaust gas generated by the air conditioner. On the other hand, occupants' feeling of comfort is another problem that should be addressed, as the air conditioner is used to achieve thermal comfort within the house.

This present research proposed one applicable solution to reduce energy consumption by air conditioners with the design of a passive house appropriate for the Indonesian climate. Bioclimatic analysis of the Indonesian climate described in the previous section gives a full explanation about possible passive strategies suitable to the corresponding climate. The next stage following the bioclimatic analysis is the validation of the strategy proposed. As walls are the largest portion of the building envelope, this section outlines the effectiveness of alternate walls by an investigation of the discomfort hours within a year. The discomfort hours are defined when the indoor air temperature is out of the comfort zone $\left(26.8 \pm 1.5^{\circ} \mathrm{C}\right)$. The Energyplus 8.5 simulation program was used to investigate indoor air temperature in three habitable rooms in the house.

\subsection{Typical Residential House in Indonesia}

A typical residential house to investigate the performance in the house is shown in Figure 7, and the house is set for four family members and has a total floor area of $54 \mathrm{~m}^{2}$. It has two bedrooms (one main bedroom and one child's bedroom, one kitchen, one living room and one bathroom). Materials and the properties for the house envelopes are present in Table 16. The electrical appliances used frequently by the occupant including time usage needed for the simulation are presented in Table 17. The energy simulation is limited to a free running house without an air conditioner because the final aim of this research is to design the passive house in Indonesia. The weather data used for the simulation are hourly data for Jakarta gathered from Green Building Studio [53]. The house is in the north direction, and the air change rate is set as $1 / \mathrm{h}$. 

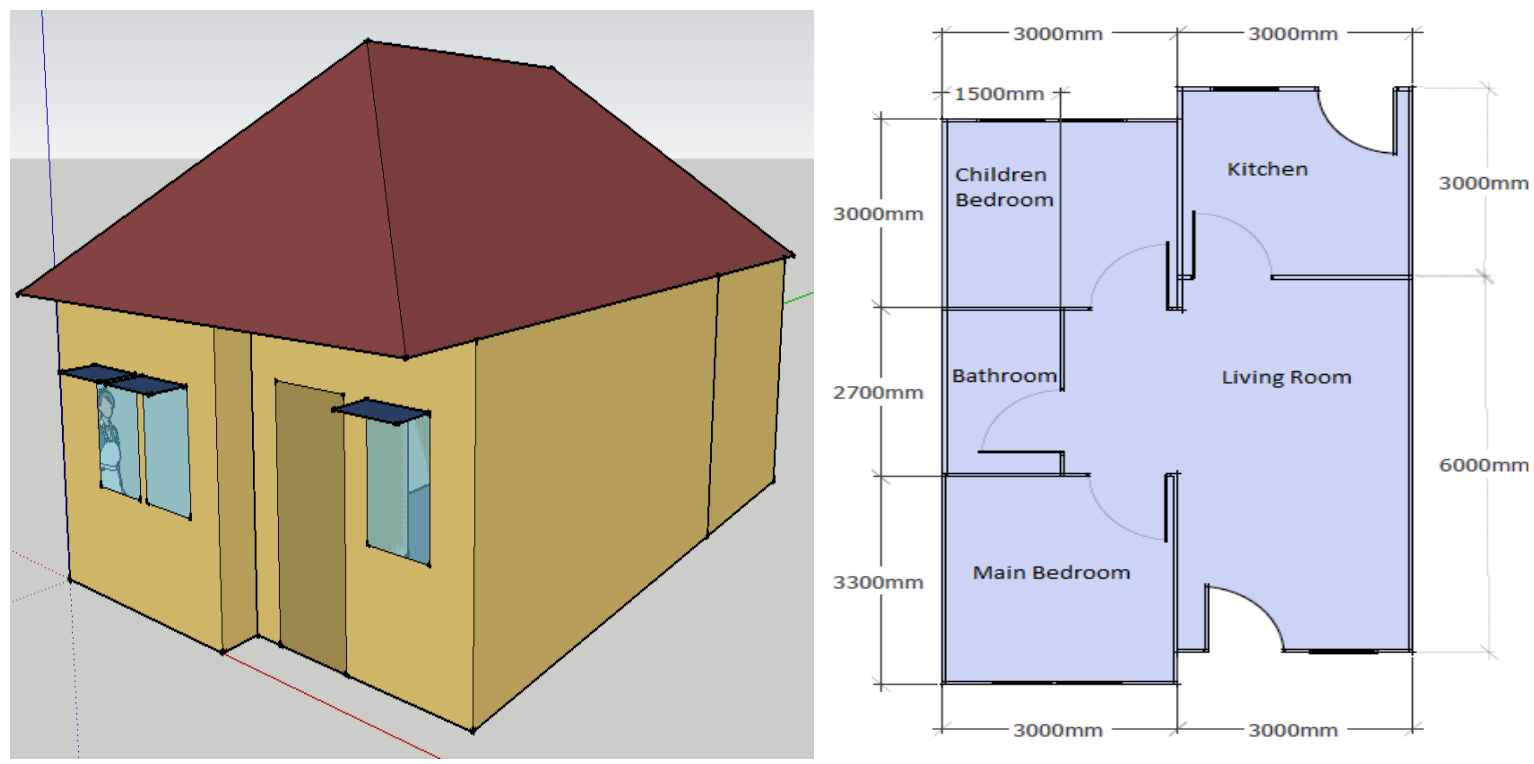

Figure 7. Typical house in Indonesia.

Table 16. House envelopes material and thermal properties of each layer.

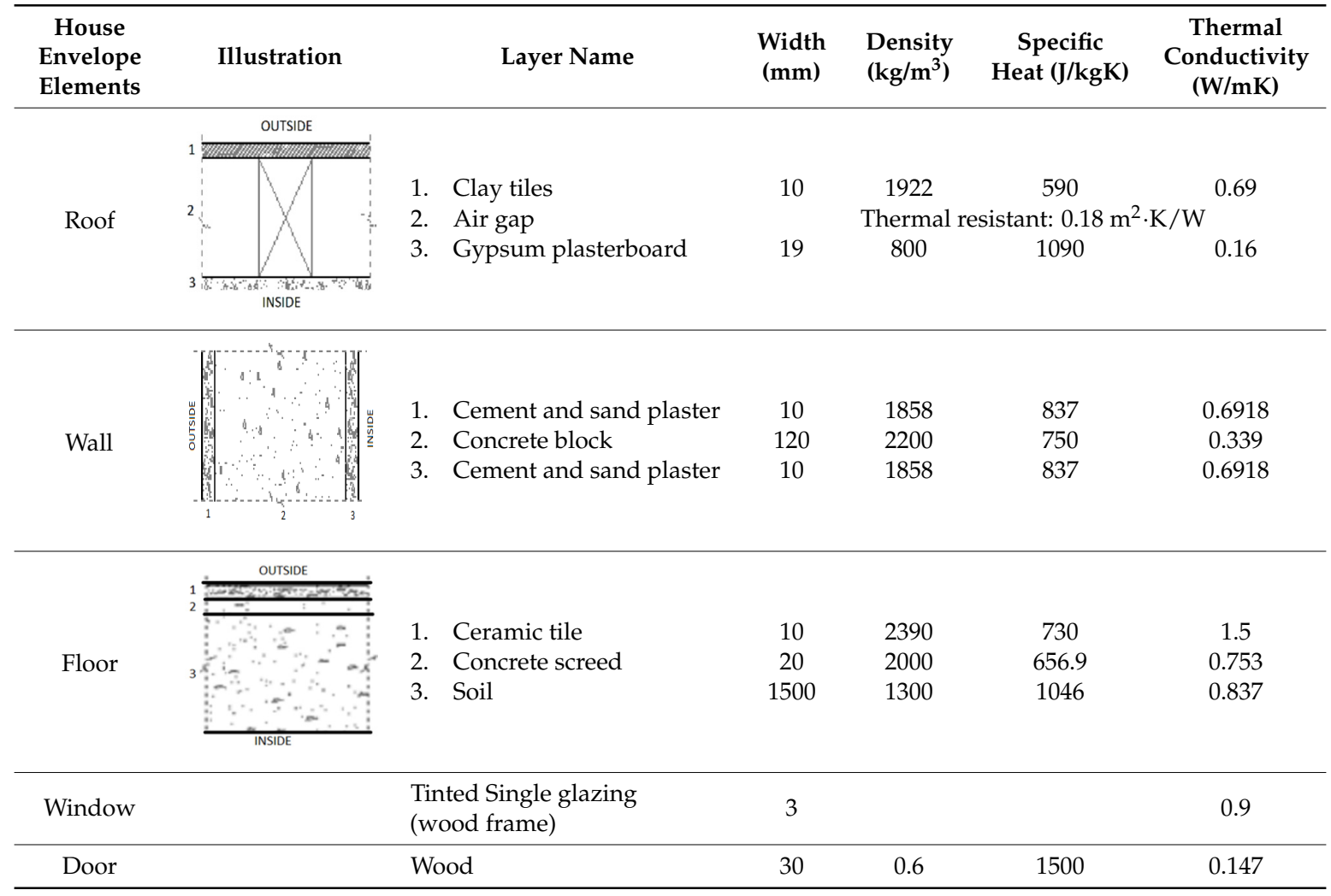


Table 17. Lighting, electrical appliances list and the usage.

\begin{tabular}{ccccc}
\hline Room & $\begin{array}{c}\text { Lighting } \\
\text { Power (Watt) }\end{array}$ & $\begin{array}{c}\text { Electrical } \\
\text { Appliances }\end{array}$ & $\begin{array}{c}\text { Appliances } \\
\text { Power (Watt) }\end{array}$ & Appliances Usage \\
\hline \multirow{2}{*}{ Main bedroom } & \multirow{2}{*}{40} & $\begin{array}{c}\text { Fan } \\
\text { Laptop } \\
\text { Hand phone }\end{array}$ & $\begin{array}{c}100 \\
20\end{array}$ & $\begin{array}{c}\text { h/day } \\
2 \mathrm{~h} / \text { day } \\
2 \mathrm{~h} / \text { day }\end{array}$ \\
\hline Bathroom & 25 & Washing machine & 250 & $4 \mathrm{~h} /$ week \\
\hline Children bedroom & 40 & Fan & 100 & $8 \mathrm{~h} /$ day \\
\hline \multirow{2}{*}{ Living room } & \multirow{2}{*}{40} & Television & 240 & $8 \mathrm{~h} /$ day \\
& \multirow{2}{*}{ Kitchen } & Fan & 100 & $8 \mathrm{~h} /$ day \\
\hline
\end{tabular}

\subsection{Thermal Comfort in a Typical Residential House in Indonesia}

Thermal comfort analysis was done using the comfort temperature limit obtained in the previous stage of this research [30]. Based on this Predictive Comfort Temperature upgrade (PCTu), the comfort limit for Indonesian is $26.8 \pm 1.5^{\circ} \mathrm{C}$. The total discomfort hours within a year were calculated in the three habitable rooms (living room, main bedroom and children's bedroom). The occupancy of the bedroom is $8 \mathrm{~h} /$ day in the night starting from 9 p.m. -5 a.m. The living room is occupied $16 \mathrm{~h} /$ day from 5 a.m. -9 p.m. The result is shown in Table 18. The number of discomfort hours in the rooms is almost $100 \%$ of the total hours within a year.

Table 18. Number of discomfort hours in typical house in Indonesia within a year.

\begin{tabular}{ccccc}
\hline Thermal Comfort Analysis & Temperature Limit & Main Bedroom & Children's Bedroom & Living Room \\
\hline Out of comfort zone (hour) & $<25.3^{\circ} \mathrm{C}$ & 0 & 0 & 0 \\
& $>28.3^{\circ} \mathrm{C}$ & 8073 & 8548 & 8721 \\
& Total & 8073 & 8548 & 8721 \\
\hline Out of comfort zone (percentage) & $<25.3^{\circ} \mathrm{C}$ & $0 \%$ & $0 \%$ & $0 \%$ \\
& $>28.3^{\circ} \mathrm{C}$ & $92 \%$ & $98 \%$ & $100 \%$ \\
& Total & $92 \%$ & $98 \%$ & $100 \%$ \\
\hline
\end{tabular}

\subsection{Application of the Passive Strategy to a Current Typical House in Indonesia}

There are several passive strategies proposed by the bioclimatic analysis. One of the strategies is the wall material. As the walls are the largest part of the building envelope, appropriate wall material should largely affect the indoor thermal conditions. Regarding the wall material, the Mahoney Table proposed heavy walls, while the Givoni-Milne Bioclimatic chart with only two months of data (maximum temperature/relative humidity in September and November) falls to the high thermal mass area. This result is slightly confusing and therefore needs validation by an energy simulation to investigate the effectiveness of the walls. The thermal properties of the alternate walls are shown in Table 19. Another passive strategy proposed by the bioclimatic analysis is wind penetration. Accordingly, as a passive strategy, the air change rate was increased to $2 / \mathrm{h}$ in the bedroom and $5 / \mathrm{h}$ in the living room to promote the wind in the house. The window in the living room is open from 5 a.m. -6 p.m., while in the bedroom, it is open from 5 p.m. -5 a.m. to allow night ventilation due to the occupancy of each room.

The result in Table 20 presents that heavy walls failed at reducing the discomfort hours, while the light walls provide a slope on the number of discomfort hours in the three rooms between $20 \%$ and $31 \%$ in comparison with the typical house. This result confirms the evidence that light walls are preferable in tropical climates. The light weight concrete chosen here is Autoclaved Aerated Concrete (AAC), which in Indonesia is known as Hebel. Hebel is available in Indonesia, but the usage is very 
limited due to its high price. Therefore, this present research can be used as a base to encourage people to use Hebel of the wall material.

Natural ventilation is well known to be the least expensive and easiest to implement in tropical climates. In this present research, a combination of light wall material and night ventilation proved to decrease the discomfort hours in the bedroom. Thus, attention should have been paid to problems with insects, such as mosquitoes. An additional mosquito netting barrier might be installed in the window. Attention should be paid to the security in the application of night ventilation. Appropriate windows might be a solution for this problem. The number of discomfort hours by the application of the passive strategy presented in this research $(61 \%-78 \%$ of total hours) still can be reduced by adding more passive strategies, such as a shading strategy and an open space outside the house. Future research should be done to compare the appropriate design to get fewer discomfort hours until it meets the passive house standard.

Table 19. Thermal properties of the alternate walls.

\begin{tabular}{|c|c|c|c|c|c|c|c|}
\hline $\begin{array}{l}\text { Type of } \\
\text { Wall }\end{array}$ & Illustration & & Layer Name & $\begin{array}{l}\text { Width } \\
(\mathrm{mm})\end{array}$ & $\begin{array}{l}\text { Density } \\
\left(\mathrm{kg} / \mathrm{m}^{3}\right)\end{array}$ & $\begin{array}{c}\text { Specific } \\
\text { Heat }(\mathrm{J} / \mathrm{kgK})\end{array}$ & $\begin{array}{c}\text { Thermal } \\
\text { Conductivity } \\
\text { (W/mK) }\end{array}$ \\
\hline $\begin{array}{l}\text { Heavy } \\
\text { wall }\end{array}$ & $\begin{array}{l}1 \\
0 \\
4 \\
4 \\
2\end{array}$ & $\begin{array}{l}2 . \\
3 .\end{array}$ & $\begin{array}{l}\text { Cement and } \\
\text { sand plaster } \\
\text { Heavy concrete } \\
\text { Cement and } \\
\text { sand plaster }\end{array}$ & $\begin{array}{l}10 \\
20 \\
10\end{array}$ & $\begin{array}{l}1250 \\
2243 \\
1250\end{array}$ & $\begin{array}{c}1088 \\
837 \\
1088\end{array}$ & $\begin{array}{l}0.431 \\
1.729 \\
0.431\end{array}$ \\
\hline Light wall & 4 & 1. & $\begin{array}{l}\text { Cement and } \\
\text { sand plaster } \\
\text { Autoclaved } \\
\text { aerated concrete } \\
\text { Cement and } \\
\text { sand plaster }\end{array}$ & $\begin{array}{l}10 \\
10 \\
10\end{array}$ & $\begin{array}{c}1250 \\
512.52 \\
1250\end{array}$ & $\begin{array}{c}1088 \\
1046.69 \\
1088\end{array}$ & $\begin{array}{c}0.431 \\
0.1344 \\
0.431\end{array}$ \\
\hline
\end{tabular}

Table 20. Number of discomfort hours in house with alternate walls within a year.

\begin{tabular}{|c|c|c|c|c|c|}
\hline Type of Wall & Thermal Comfort Analysis & $\begin{array}{c}\text { Temperature } \\
\text { Limit }\end{array}$ & $\begin{array}{c}\text { Main } \\
\text { Bedroom }\end{array}$ & $\begin{array}{l}\text { Children's } \\
\text { Bedroom }\end{array}$ & $\begin{array}{l}\text { Living } \\
\text { Room }\end{array}$ \\
\hline \multirow[t]{6}{*}{ Heavy Wall } & Out of comfort zone (hour) & $<25.3^{\circ} \mathrm{C}$ & 0 & 0 & 0 \\
\hline & & $>28.3{ }^{\circ} \mathrm{C}$ & 8158 & 8576 & 8716 \\
\hline & & Total & 8158 & 8576 & 8716 \\
\hline & Out of comfort zone (percentage) & $<25.3^{\circ} \mathrm{C}$ & $0 \%$ & $0 \%$ & $0 \%$ \\
\hline & & $>26.3^{\circ} \mathrm{C}$ & $93 \%$ & $98 \%$ & $99 \%$ \\
\hline & & Total & $93 \%$ & $98 \%$ & $99 \%$ \\
\hline \multirow[t]{6}{*}{ Light Wall } & Out of comfort zone (hour) & $<25.3^{\circ} \mathrm{C}$ & 21 & 0 & 106 \\
\hline & & $>28.3^{\circ} \mathrm{C}$ & 5324 & 6832 & 6738 \\
\hline & & Total & 5345 & 6832 & 6844 \\
\hline & Out of comfort zone (percentage) & $<25.3^{\circ} \mathrm{C}$ & $0 \%$ & $0 \%$ & $1 \%$ \\
\hline & & $>26.3^{\circ} \mathrm{C}$ & $61 \%$ & $78 \%$ & $77 \%$ \\
\hline & & Total & $61 \%$ & $78 \%$ & $78 \%$ \\
\hline
\end{tabular}

\section{Conclusions}

The following findings are drawn based on the results obtained from the bioclimatic analysis and energy simulation.

According to the Olgyay Bioclimatic chart, the climate in Jakarta is particularly humid and sultry throughout the year. Wind is required to overcome humidity problems and can be effectively 
addressed by installing an opening, such as a window, for ventilation. Furthermore, a shading device is also required to minimize solar radiation entering the building. The Givoni-Milne Bioclimatic chart evidently marks an almost similar result as the Olgyay Method. A need for natural ventilation is also proposed due to the high temperature and high level of humidity, and a shading device is recommended due to the temperature. The Mahoney Table marked a demand to orient the building to the north-south (long axis from the east-west) to reduce high solar penetration and also provide an open space for breeze penetration. An opening of about $20 \%-35 \%$ is recommended for the north and south walls at body height, but protection on the openings against direct sunlight is also needed. Heavy walls and roofs with more than eight hours of time lag will easily protect against the heat coming into the building envelope. Furthermore, the relatively high level of rainfall indicates the requirement for a protection device for rain penetration. In addition, the new finding in this research is for building in the north direction; the average shading coefficients range between $36 \%$ and $64 \%$ annually. Energyplus simulation showed a reduction in the total number of discomfort hours in a year to be around $20 \%-31 \%$ in the three habitable rooms when the light wall is combined with night ventilation applied in the current house.

The previous research works $[17,18]$ were done in the development of passive houses in warm climates, hot and humid or dry and tropical climates. Several design parameters were examined by dynamic simulation, and a reference passive house with the optimal value of each parameter was established. Thus, the availability of the appropriate material in each region was not investigated in this study. If the material is not available domestically and is exported from somewhere else, it will increase the cost of the construction. The detailed specification and installation placement of the air and humidity recovery device suggested in this study are not clearly defined. The effect of micro climate was not taken into account in this research; whereas, a good micro climate is proven to reduce the ambient temperature [54].

According to the definition of a passive house defined by Passivhaus Institute, the thermal comfort standard used for passive house certification is ISO 7730, which is based on the heat balance study by Fanger [14]. However, the adaptive thermal comfort is proven to be more adequately describe the comfort condition in tropical climates, such as Indonesia, in comparison with the steady state model $[26,30,33]$. Therefore, it is a challenge to examine the possibility for the applicability of adaptive thermal comfort to the requirement of passive houses. Moreover, an investigation to compare the gap (if any) of energy needs to achieve the comfort level by both adaptive and conventional comfort is also needed.

Although the climate analysis in this present research was done in Jakarta, the result can be applied to most of the regions in Indonesia. Future research should be done to investigate another design parameter proposed by the climatic analysis, including the ventilation design and open spacing. As was suggested in the previous research that airtight buildings with a heat and humidity recovery ventilation system are rare and since there are almost none in residential buildings in Indonesia, it is a challenge for building construction companies to accommodate this need. The specific design, including the size and installation placement of heat and humidity recovery suitable for a residential house, which should be cost-effective, requires further research. Furthermore, a study to determine the optimum design, size and placement of the open space area to serve for a good micro climate for a residential house, including the sensitivity analysis on the effect of energy gain/loss, is also needed. Not only an energy building simulation program, but a Computational Fluid Dynamics (CFD) program will be advantageous in revealing and verifying the most appropriate design applicable in the tropical climate country of Indonesia. When an energy performance building program calculates the energy needs, a CFD program figures out the temperature distribution and energy/heat flow around and inside the building. The CFD will also help to know the leakage in the building construction before the building built.

Acknowledgments: The author would like to show the gratitude to the Ministry of Education, Culture, Sport, Science and Technology (MEXT), Japan, for support during the study. 
Author Contributions: The study was performed and written by Santy. Hiroshi Matsumoto and Kazuyo Tsuzuki are the academic supervisors, while Lusi Susanti contributed together with Santy to analyze the result.

Conflicts of Interest: The authors declare no conflict of interest.

\section{References}

1. Green Building Studio. Available online: https://gbs.autodesk.com/GBS/ (accessed on 10 June 2016).

2. Badan Pusat Statistik Indonesia. Statistik Indonesia 2015; Badan Pusat Statistik-Statistic Indonesia: Jakarta, Indonesia, 2015.

3. Indonesia Map with Cities-Blank Outline Map of Indonesia. Available online: http://indonesiamap.facts. co/indonesiamapof/indonesiamap.php (accessed on 30 November 2016).

4. Sayigh, A.; Marafia, A.H. Chapter 1-Thermal comfort and the development of Bioclimatic concept in building design. Renew. Sustain. Energy Rev. 1998, 2, 3-24. [CrossRef]

5. Milne, M.; Givoni, B. Architectural Design Based on Climate in Energy Conservation Through Building Design; Watson, D., Ed.; McGraw-Hill, Inc.: New York, NY, USA, 1979.

6. Lam, J.C.; Yang, L.; Liu, J. Development of passive design zones in China using Bioclimatic approach. Energy Convers. Manag. 2006, 47, 746-762. [CrossRef]

7. Rakoto-Joseph, O.; Garde, F.; David, M.; Adelard, L.; Randriamanantany, Z.A. Development of climatic zones and passive solar design in Madagascar. Energy Convers. Manag. 2009, 50, 1004-1010. [CrossRef]

8. Luo, M.; Lin, B.; Cao, B. Approach to choose proper passive design strategies for residential buildings. In Proceedings of the 8th International Symposium on Heating, Ventilation and Air Conditioning, Xi'an, China, 19-21 October 2013.

9. Singh, M.K.; Mahapatra, S.; Atreya, S.K. Development of bio-climatic zones in north-east India. Energy Build. 2007, 39, 1250-1257. [CrossRef]

10. Al-Azri, N.; Zurigat, Y.; Al-Rawahi, N. Development of Bioclimatic Chart for Passive Building Design in Muscat-Oman. In Proceedings of the International Conference on Renewable Energies and Power Quality, Santiago de Compostela, Spain, 28-30 March 2012.

11. Visitsak, S. An Evaluation of the Bioclimatic Chart for Choosing Design Strategies for a Thermostatically-Controlled Residence in Selected Climates; Texas A\&M University: College Station, TX, USA, 2007.

12. Bodach, S.; Lang, W.; Hamhaber, J. Climate responsive building design strategies of vernacular architecture in Nepal. Energy Build. 2014, 81, 227-242. [CrossRef]

13. Passipedia. The Passive House-Definition. Available online: https://passipedia.org/basics/the_passive_ house_-_definition (accessed on 11 February 2017).

14. Fanger, P.O. Thermal Comfort: Analysis and Applications in Environmental Engineering; Danish Technical Press: Copenhagen, Denmark, 1970.

15. Schnieders, J. Adaptive Versus Heat Balance Comfort Models. Available online: https://passipedia. org/basics/building_physics_-_basics/thermal_comfort/heat_balance_vs_comfort_models (accessed on 12 February 2017).

16. Passive House Institute. Criteria for the Passive House, EnerPHit and PHI Low Energy Building Standard. Available online: http://passiv.de/downloads/03_building_criteria_en.pdf (accessed on 13 February 2017).

17. Schnieders, J.; Feist, W.; Rongen, L. Passive Houses for different climate zones. Energy Build. 2015, 105, 71-87. [CrossRef]

18. Passipedia. Passive House in Different Climate. Available online: https://passipedia.org/basics/passive_ houses_in_different_climates (accessed on 11 February 2017).

19. Passive House Institute. Passive House Database. Available online: http:/ /www.passivhausprojekte.de/ index.php?lang=en\#d_4340 (accessed on 14 February 2017).

20. De Dear, R.J.; Brager, G.S. Thermal comfort in naturally ventilated buildings: Revisions to ASHRAE Standard 55. Energy Build. 2002, 34, 549-561. [CrossRef]

21. Nicol, J.F.; Humphreys, M.A. Adaptive thermal comfort and sustainable thermal standards for buildings. Energy Build. 2002, 34, 563-572. [CrossRef]

22. Nicol, F. Adaptive thermal comfort standards in the hot-humid tropics. Energy Build. 2004, 36, 628-637. [CrossRef] 
23. De Dear, R.; Brager, G. Developing an adaptive model of thermal comfort and preference. ASHRAE Trans. 1998, 104, 1-18.

24. Nguyen, A.T.; Singh, M.K.; Reiter, S. An adaptive thermal comfort model for hot humid South-East Asia. Build. Environ. 2012, 56, 291-300. [CrossRef]

25. Indraganti, M.; Ooka, R.; Rijal, H.B.; Brager, G.S. Adaptive model of thermal comfort for offices in hot and humid climates of India. Build. Environ. 2014, 74, 39-53. [CrossRef]

26. Karyono, T. Predicting Comfort Temperature in Indonesia, an Initial Step to Reduce Cooling Energy Consumption. Buildings 2015, 5, 802-813. [CrossRef]

27. Toe, D.H.C.; Kubota, T. Development of an adaptive thermal comfort equation for naturally ventilated buildings in hot-humid climates using ASHRAE RP-884 database. Front. Archit. Res. 2013, 2, 278-291. [CrossRef]

28. Hooi, D.; Toe, C.; Kubota, T. A Review of Adaptive Model of Thermal Comfort for Naturally Ventilated Buildings in Hot-Humid Climate. In Proccedings of 8th International Symposium on Architectural Interchanges in Asia (ISAIA), Kitakyushu, Japan, 9-12 November 2010.

29. Indraganti, M.; Rao, K.D. Effect of age, gender, economic group and tenure on thermal comfort: A field study in residential buildings in hot and dry climate with seasonal variations. Energy Build. 2010, 42, 273-281. [CrossRef]

30. Santy, S.; Matsumoto, H.; Susanti, L. Development of a Passive House Standard for Tropical Climates (Indonesia)-The Initial Stage. In Proceedings of 12th REHVA World Congress, CLIMA Conference, Aalborg, Denmark, 22-25 May, 2016.

31. Feriadi, H.; Wong, N.H. Thermal comfort for naturally ventilated houses in Indonesia. Energy Build. 2004, 36, 614-626. [CrossRef]

32. Luo, M.; Cao, B.; Zhou, X.; Li, M.; Zhang, J.; Ouyang, Q.; Zhu, Y. Can personal control influence human thermal comfort? A field study in residential buildings in China in winter. Energy Build. 2014, 72, 411-418. [CrossRef]

33. Sujatmiko, W. Development of the Adaptive Thermal Comfort Standard for Residential in Indonesia. J. Hum. Settlements 2011, 3, 88-99.

34. SNI Standard Nasional Indonesia. Konservasi Energi Sistem Tata Udara Bangunan Gedung; Badan Standarisasi Nasional: Jakarta, Indonesia, 2011.

35. Olgyay, V.; Olgyay, A. Olgay 1992; Van Nostrand New York: New York, NY, USA, 1992.

36. Bodach, S.; Sc, M. Developing Bioclimatic Zones and Passive Solar Design Strategies for Nepal. In Proceedings of the 30th International PLEA Conference, Ahmedabad, India, 16-18 December 2014.

37. Pourvahidi, P. Bioclimatic Analysis of Vernacular Iranian Architecture; Eastern Mediterranean University: Gazimağusa, Cyprus, 2010.

38. Wan, K.K.W.; Li, D.H.W.; Yang, L.; Lam, J.C. Climate classifications and building energy use implications in China. Energy Build. 2010, 42, 1463-1471. [CrossRef]

39. Sealey, A. Introduction to Building Climatology-Chapter 10-The Mahoney Tables.pdf. In Introduction to Building Climatology; Commonwealth Association of Architects: London, UK, 1979.

40. Shi, X.; Zhu, N.; Zheng, G. The combined effect of temperature, relative humidity and work intensity on human strain in hot and humid environments. Build. Environ. 2013, 69, 72-80. [CrossRef]

41. Givoni, B. Climate Considerations in Building and Urban Design; John Wiley \& Sons: Toronto, Canada, 1998.

42. Watson, D.; Labs, K. Climatic Building Design; MacGraw Hill Inc.: New York, NY, USA, 1983.

43. Bansal, N.K.; Hauser, G.; Minke, G. Passive Building Design A Handbook of Natural Climatic Control; Elsevier Science BV: Amsterdam, The Netherlands, 1994.

44. Cheng, V.; Ng, E.; Givoni, B. Effect of envelope colour and thermal mass on indoor temperatures in hot humid climate. Solar Energy 2004, 78, 528-534. [CrossRef]

45. Zhou, J.; Zhang, G.; Lin, Y.; Li, Y. Coupling of Thermal Mass and Natural Ventilation in Buildings. Energy Build. 2008, 40, 979-986. [CrossRef]

46. Motamedi, S.; Akhavan, M. Energy Analysis of Using Thermal Mass in a Hot Humid climate. In Proceedings of the 3rd International Conference on Development, Energy, Environment, Economics (DEEE '12), Paris, France, 2-4 December 2012.

47. Autodesk Inc. AutoDesk Ecotect Weather Tools in Ecotect Software. Available online: http://usa.autodesk. com/ecotect-analysis/ (accessed on 10 March 2017). 
48. Autodesk Inc. AutoDesk Ecotect Solar Tool in Ecotect Software. Available online: http:/ /usa.autodesk.com/ ecotect-analysis / (accessed on 10 March 2017).

49. Baker, N.V. Passive and Low Energy Building Design For Tropical Island Climates. 1987.

50. Juarez, C.E.M. Impact of Thermal Mass on Energy and Comfort-A Parametric study in a Temperate and a Tropical Climate; Chalmers University of Technology: Gothenborg, Sweden, 2014.

51. Hilmawan, E. Current Situation and Chalanges in Energy Efficiency S\&L Policy Development in Indonesia. Available online: http:/ / eneken.ieej.or.jp/data/3693.pdf (accessed on 10 July 2016).

52. Katili, A.R.; Boukhanouf, R.; Wilson, R. Space Cooling in Buildings in Hot and Humid Climates-A Review of the Effect of Humidity on the Applicability of Existing Cooling Techniques. In Proccedings of 14th International Conference on Sustainable Energy Technologies (SET), Nottingham, UK, 25-27 August 2015.

53. Autodesk Inc Green Building Studio. Available online: https://gbs.autodesk.com/GBS/ (accessed on 14 July 2016).

54. Case, T.E.; Enugu, O.F.; Obi, A.N.I. The Influence of Vegetation on Microclimate in Hot Humid Tropical Environment-A Case of Enugu Urban; Arc, N.I., Ed.; OBI Department of Architecture, University of Nigeria Enugu Campus (UNEC): Enugu, Nigeria, 2014; Volume 2, pp. 28-38.

(C) 2017 by the authors. Licensee MDPI, Basel, Switzerland. This article is an open access article distributed under the terms and conditions of the Creative Commons Attribution (CC BY) license (http:/ / creativecommons.org/licenses/by/4.0/). 